\title{
Rain-fed streams dilute inorganic nutrients but subsidise organic-matter-associated nutrients in coastal waters of the northeast Pacific Ocean
}

\author{
Kyra A. St. Pierre ${ }^{1,2}$, Brian P. V. Hunt ${ }^{1,2,3}$, Suzanne E. Tank ${ }^{1,4}$, Ian Giesbrecht ${ }^{1,5}$, Maartje C. Korver ${ }^{1, a}$, \\ William C. Floyd ${ }^{6,7}$, Allison A. Oliver ${ }^{1,4, b}$, and Kenneth P. Lertzman ${ }^{1,5}$ \\ ${ }^{1}$ Hakai Institute, Tula Foundation, Heriot Bay, BC, V0P 1H0, Canada \\ ${ }^{2}$ Institute for the Oceans and Fisheries, University of British Columbia, Vancouver, BC, V6T 1Z4, Canada \\ ${ }^{3}$ Department of Earth, Ocean and Atmospheric Sciences, University of British Columbia, Vancouver, BC, V6T 1Z4, Canada \\ ${ }^{4}$ Department of Biological Sciences, University of Alberta, Edmonton, AB, T6G 2E9, Canada \\ ${ }^{5}$ School of Resource and Environmental Management, Simon Fraser University, Burnaby, BC, V5A 1S6, Canada \\ ${ }^{6}$ Ministry of Forests, Lands and Natural Resource Operations, Nanaimo, BC, V9T 6E9, Canada \\ ${ }^{7}$ Vancouver Island University, Nanaimo, BC, V9R 5S5, Canada \\ ${ }^{a}$ current address: Department of Geography, McGill University, Montréal, QC, H3A 0B9, Canada \\ ${ }^{\mathrm{b}}$ current address: Skeena Fisheries Commission, Kispiox, BC, V0J 1Y4, Canada
}

Correspondence: Kyra A. St. Pierre (k.stpierre@ oceans.ubc.ca)

Received: 23 September 2020 - Discussion started: 27 October 2020

Revised: 18 March 2021 - Accepted: 6 April 2021 - Published: 20 May 2021

\begin{abstract}
In coastal regions, rivers and streams may be important sources of nutrients limiting to primary production in marine waters; however, sampling is still rarely conducted across the land-to-ocean aquatic continuum, precluding conclusions from being drawn about connectivity between freshwater and marine systems. Here we use a more-than-4-year dataset (2014-2018) of nutrients (nitrogen, phosphorus, silica, iron) and dissolved organic carbon spanning streams draining coastal watersheds and nearshore marine surface waters along the Central Coast of British Columbia, Canada, at the heart of the North Pacific coastal temperate rainforest region. Mean freshwater and surface marine $\mathrm{N}: \mathrm{Si}: \mathrm{P}$ ratios were $5: 20: 1(\mathrm{P}: \mathrm{Fe}=1: 67)$ and $6: 11: 1$, respectively, showing relative consistency across the land-ocean interface but deviation from the extended Redfield ratio. Inorganic nutrient concentrations $\left(\mathrm{NO}_{3}^{-}+\mathrm{NO}_{2}^{-}, \mathrm{PO}_{4}^{3-}, \mathrm{Si}(\mathrm{OH})_{4}\right)$ in fresh waters were less than in the receiving marine environment, indicating that freshwater nutrient inputs in this region were of little importance to - or even diluted - the pool of readily available inorganic nutrients in nearshore waters. Conversely, fresh waters increased the pool of organic-matter-associated nutrients, namely dissolved organic nitrogen and iron. The organic-matter-rich landscapes of the region yielded glob-
\end{abstract}

ally significant quantities of dissolved organic nitrogen (304$381 \mathrm{~kg} \mathrm{~km}^{-2} \mathrm{yr}^{-1}$ ) and iron (463-596 $\mathrm{kg} \mathrm{km}^{-2} \mathrm{yr}^{-1}$ ), thus acting as important sources of potentially limiting nutrients to both nearshore and offshore waters. These exports may subsidise heterotrophic microbial communities capable of directly consuming and remineralising these nutrients, potentially compensating for the dilution of inorganic nutrients by freshwater inputs. We highlight the need to better understand nutrient limitation in coastal waters and for concerted research efforts to study the spatial and temporal dynamism at the land-ocean interface along the northeast Pacific coast.

\section{Introduction}

All living organisms require a combination of more than 20 naturally occurring chemical elements (Sterner and Elser, 2002). Whereas early studies were solely focused on carbon $(\mathrm{C})$, nitrogen $(\mathrm{N})$, and phosphorus $(\mathrm{P})$, the fundamental building blocks of life (Redfield, 1934), the crucial role of other nutrients like silicon ( $\mathrm{Si}$, hereafter referred to as orthosilicic acid, $\left.\mathrm{Si}(\mathrm{OH})_{4}\right)$ and iron $(\mathrm{Fe})$ has long been recog- 
nised (Ho et al., 2003). Primary producers like phytoplankton, whose carbon uptake capabilities are intrinsic to the coastal carbon cycle (Bauer et al., 2013), must obtain these essential nutrients directly from their environment and are thus dependent on the sources and sinks that govern nutrient speciation and availability.

Alfred Redfield established that marine phytoplankton are generally composed of $\mathrm{C}, \mathrm{N}$, and $\mathrm{P}$ in a ratio of $106: 16: 1$ (Redfield, 1934), a global average that has been shown to vary over space (Martiny et al., 2013). Updated iterations of the ratio include $\mathrm{Si}(\mathrm{OH})_{4}$ and $\mathrm{Fe}(\mathrm{C}: \mathrm{N}: \mathrm{Si}: \mathrm{P}: \mathrm{Fe}=106$ : $16: 15: 1: 0.1-0.01)$ among other elements, in recognition of the important role that these elements play in fundamental cellular metabolism and growth (Sterner and Elser, 2002; Ho et al., 2003), with special reference to diatoms in the case of $\mathrm{Si}(\mathrm{OH})_{4}$ (Brzezinski, 1985). We now understand that nutrient limitation of primary production is determined by biological demand, available supply, and supply relative to that of other essential elements (Welti et al., 2017).

One of the potential sources of limiting nutrients in marine waters, especially in coastal environments, is subsidies from terrestrial ecosystems on adjacent landmasses (Sakamaki and Richardson, 2008; Harding and Reynolds, 2014; Moore et al., 2013). As rivers and streams flow from their headwaters to coastal ecosystems, they integrate processes happening across their watersheds, transporting the products of erosion, weathering, biological production, and decomposition, all sources of nutrients potentially limiting to primary production in the marine environment (Bouwman et al., 2013). The land-to-ocean aquatic continuum (LOAC) concept acknowledges that what happens on land has important consequences for water quality and productivity in coastal regions (Xenopoulos et al., 2017). However, the LOAC has typically been applied either by freshwater scientists to describe changes in water quality across watersheds, leading up to but not including coastal waters (e.g., Bouwman et al., 2013; Weyhenmeyer and Conley, 2017), or by marine scientists to infer freshwater inputs from salinity gradients across nearshore environments (e.g., Wetz et al., 2006; Cuevas et al., 2019). Each of these approaches, while valuable, relies on inference about the neighbouring ecosystems, thus overlooking potential local deviations in the relationship (i.e., mixing, subsidy, loss) between freshwater and marine ecosystems from average or assumed conditions.

The North Pacific coastal temperate rainforest (NPCTR) region of North America, which extends from northern California to the Gulf of Alaska (Fig. 1; Alaback, 1996), receives on average $2000 \mathrm{~mm}$ of rainfall per year, with some locations receiving upwards of $4000 \mathrm{~mm}$ (DellaSala, 2011). High rainfall, combined with snow and glacial melt from high elevations, translates to intense stream and river discharge (Royer, 1982; Neal et al., 2010; Morrison et al., 2012), making the connection between land and sea across this region particularly strong (Fleming et al., 2016; O'Neel et al., 2015). Indeed, along the rainfall-dominated outer coast of British
Columbia, the composition of marine dissolved organic carbon (DOC) in ocean surface waters very closely resembles that of freshwater DOC during the winter months when high rainfall-induced inputs of DOC may favour microbial heterotrophy (St. Pierre et al., 2020a). While the large organic carbon stocks in soils across the NPCTR (McNicol et al., 2019) have made DOC a major focus of study (Fellman et al., 2009a, b; Oliver et al., 2017; Hood et al., 2006; and others), we do not fully understand how these high freshwater exports impact nutrient availability and limitation in nearshore waters across the region (but see for example Wetz et al., 2006). This remains a key oversight given the strong association between nutrients and organic matter for potentially limiting elements like nitrogen and iron (Meybeck, 1982). The landocean connection across this region is further modulated by large-scale climate anomalies like the El Niño-Southern Oscillation (ENSO), which affects air temperature, precipitation, and circulation in receiving marine waters (Ward et al., 2010). While these anomalies are known to affect large watersheds (Ward et al., 2010), their effect on the many small watersheds of the NPCTR has rarely been examined.

Since 2014, routine monthly water quality surveys have been conducted in both coastal marine and fresh waters across the Calvert and Hecate islands at the mid-latitudes of the NPCTR along the Central Coast of British Columbia, Canada $\left(51.7^{\circ} \mathrm{N}, 128.0^{\circ} \mathrm{W}\right.$; Fig. 1) (Giesbrecht et al., 2016). The Calvert and Hecate Island systems are broadly representative of the many small rainfall-dominated coastal watersheds that define the outer coast of the NPCTR in British Columbia and Alaska (Oliver et al., 2017). Because of the large freshwater fluxes from the NPCTR to the coastal ocean, it is an ideal region in which to examine the connection between land and sea (Bidlack et al., 2021). To address the knowledge gaps highlighted above, we endeavoured to (1) understand seasonal variability in inorganic and organic nutrient concentrations and stoichiometry in nearshore marine waters, (2) quantify and characterise temporal variability in freshwater nutrient inputs to marine waters, and (3) assess whether fresh waters constitute an important source of potentially limiting nutrients to marine ecosystems in this region. This more-than-4-year dataset offers insights into the spatial and temporal variability in nutrient stoichiometry across the LOAC, highlighting the possible role of small rivers and streams in regulating biological productivity in nearshore waters.

\section{Methods}

\subsection{Site descriptions}

The Kwakshua $\left(26.5 \mathrm{~km}^{2}\right)$ and Meay $\left(8.6 \mathrm{~km}^{2}\right)$ channels separate the Calvert and Hecate islands within the Hakai Luxvbalis Conservancy along the Central Coast of British Columbia, Canada (Fig. 1). Within the channels, surface wa- 


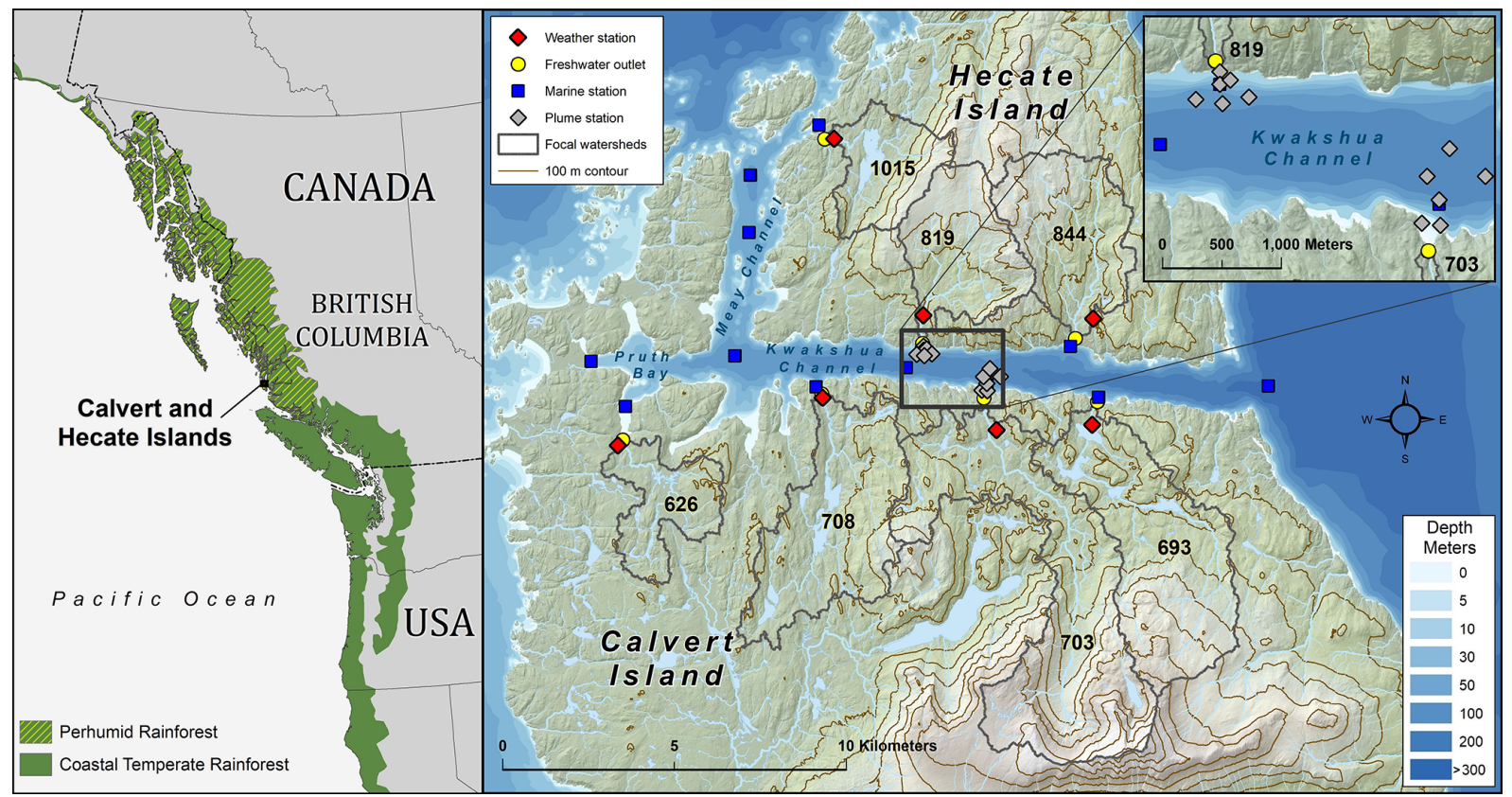

Figure 1. Map of study area within the North Pacific coastal temperate rainforest (NPCTR) region. All sampled freshwater $(n=7)$ and marine stations $(n=13)$ are shown. Inset indicates the sampling stations for the riverine plume surveys. On the left panel, the basemap is from Natural Earth data, and the NPCTR delineation is based on the detailed mapping by Ecotrust et al. (2015).

ters $(0-5 \mathrm{~m})$ are typically quite fresh $(<30$ salinity units) relative to the rest of the water column $(\sim 30-33$ salinity units). The channel system is sheltered from direct offshore influences by Calvert Island but exchanges waters with Fitz Hugh Sound to the east through Kwakshua Channel and with Hakai Pass and Queen Charlotte Sound to the northwest through Meay Channel. Pruth Bay $\left(3.1 \mathrm{~km}^{2}\right)$ connects the Meay and Kwakshua channels. We hereafter refer to the combined areas of Pruth Bay and the Meay and Kwakshua channels as the Kwakshua Channel system. Thirteen marine stations were sampled throughout the Kwakshua Channel system: six were approximately mid-channel, and seven were closer to the shoreline and associated with freshwater outlets (Fig. 1, Table S1). Fitz Hugh Sound and Hakai Pass are also influenced by large freshwater fluxes from the British Columbia mainland, which affect marine nutrient dynamics within the system against which the watersheds are compared; however, quantifying the influence of these mainland freshwater exports is beyond the scope of this study.

The Calvert and Hecate islands are characterised by bog forests and extensive wetlands and are located within the hypermaritime zone (i.e., rainfall-dominated outer coast) of the perhumid NPCTR (Meidinger and Pojar, 1991; Thompson et al., 2016). Mean annual 1981-2010 air temperature and precipitation near sea level on the islands were $8.93 \pm 0.20^{\circ} \mathrm{C}$ and $2800 \pm 49 \mathrm{~mm}$, respectively (http://www. climatewna.com/ (last access: 25 May 2020), Wang et al., 2016). Precipitation on the Calvert and Hecate islands is primarily in the form of rain; however, above $500 \mathrm{~m}$ elevation, seasonal snowpacks over $2 \mathrm{~m}$ deep can develop, corresponding to between 600 and $1000 \mathrm{~mm}$ of stored water. Snow in watersheds with significant areas of elevation greater than $500 \mathrm{~m}$ can contribute to a modest spring freshet, though all elevations have the potential to contribute to rain-on-snow events through late fall and early winter. The geology underlying the region is acidic plutonic, dominated by silicate and aluminium oxides, as well as iron oxides towards the eastern coasts of the islands (Roddick, 1996). This geology is overlain by organic-rich podzol and folic histosol soils, with thick hemists in depressional areas, and open wetlands and short wet forests composed of western redcedar, yellowcedar, shore pine, and western hemlock (Oliver et al., 2017). Seven streams draining coastal watersheds of the Kwakshua Channel system have been routinely sampled for a suite of dissolved chemical species (see Table S2). These watersheds, previously described in detail in Oliver et al. (2017) and summarised in Table S3, cumulatively account for $67.4 \%$ of the terrestrial drainage area $\left(69.6 \mathrm{~km}^{2}\right)$ of the combined channels. These watersheds range between 3.2 and $12.8 \mathrm{~km}^{2}$ with extensive but variable coverage by wetlands $(23.8 \%-50.2 \%)$ and lakes $(0.3 \%-9.1 \%)$ and mean slopes between $21.7 \%$ and $40.3 \%$ (Gonzalez Arriola et al., 2015; Oliver et al., 2017).

\subsubsection{Seasonality and wider-scale climate anomalies}

The NPCTR is characterised by high seasonality across both marine and freshwater systems. The spring transition occurs between March and May each year (Thomson et al., 
2014), with a shift towards northwesterly winds favouring the propagation of nutrient-rich upwelled waters onto the shelf and into inner passage waters, including Kwakshua Channel (Hunt et al., 2018). Increased solar radiation favours a phytoplankton bloom coinciding with the spring transition and high productivity through to approximately August. Between September and November, downwelling-favourable southeasterly winds begin to dominate. This change overlaps with a marked increase in rainfall and therefore terrestrial runoff to the marine system, which persists from around October through to March (St. Pierre et al., 2020a).

The wider northeast Pacific region is also characterised by large-scale climate cycles, including the Pacific Decadal Oscillation (PDO) and the El Niño-Southern Oscillation (ENSO), both of which can have a large effect on temperature (air, surface water) and precipitation patterns (Kiffney et al., 2002). Variability in the PDO occurs over timescales of $10+$ years and is thus outside the scope of the present study. The study period was characterised by large fluctuations in the ENSO, which are later discussed.

\subsection{Sampling scheme and sample collection}

Field surveys of both marine and fresh waters were conducted on an approximately monthly basis between $1 \mathrm{Au}-$ gust 2014 and 31 December 2018 (4 years, 5 months) by staff at the Hakai Institute's Calvert Island Field Station. Briefly, 13 marine stations and seven freshwater streams were sampled to provide information on spatial and temporal variability in marine waters within the context of variable freshwater inputs.

\subsubsection{Marine stations in the Kwakshua and Meay channels}

Marine water samples were collected from a boat at discrete depths $(0,1$, and $5 \mathrm{~m})$ within the upper water column using a Niskin water sampler across the 13 marine stations. Samples for combined nitrate-nitrite $\left(\mathrm{NO}_{3}^{-}+\mathrm{NO}_{2}^{-}\right.$; hereafter shortened to $\left.\mathrm{NO}_{3}^{-}\right)$, orthophosphate $\left(\mathrm{PO}_{4}^{3-}\right)$, silicic acid $\left(\mathrm{Si}(\mathrm{OH})_{4}\right)$, and dissolved organic carbon (DOC) were filtered through $0.45 \mu \mathrm{m}$ Millipore ${ }^{\circledR}$ Millex-HP hydrophilic polyethyl sulfonate (PES) filters in the field and kept on ice until returning to the field station. Following sample collection on the boat, the basic properties (temperature, salinity, conductivity) of the collected water were measured using a calibrated, marine-sample-specific YSI sonde in a pre-rinsed container.

\subsubsection{Rainforest streams}

In this study, we integrated the results of two freshwater sampling programs conducted between 1 August 2014 and 31 December 2018: (1) routine monthly samplings of the seven watersheds at their outlets to the Kwakshua Chan- nel system and (2) targeted rainfall event samplings of the streams over the rising and falling limbs of the hydrographs.

Discharge, rainfall, and air temperature were monitored continuously at each of the seven watersheds. Climate stations were established adjacent to the seven outlet streams at low elevation (range 10-90 m.a.s.l; Table S3), near the stream sampling location. Air temperature and precipitation were recorded at $5 \mathrm{~min}$ intervals and aggregated to daily statistics for temperature (mean, minimum, maximum) or totals for precipitation. Discharge was continuously measured at $5 \mathrm{~min}$ intervals, but the dataset was filtered to 15 min intervals for flux model construction, as in Oliver et al. (2017) and St. Pierre al. (2020a). Rating curve construction and discharge calculation are described in detail in Oliver et al. (2017) and updated in Korver et al. (2019a). Weather data from Mt. Buxton ( 1000 m.a.s.l.), the highest point on Calvert Island, were also extracted for the period of record from the ClimateNA spatially downscaled model (http://www.climatewna.com/ (last access: 25 May 2020); Wang et al., 2016) for comparison to the sea level stations.

Standardised monthly temperature and precipitation anomalies were calculated relative to the 1981-2010 climate normal for each station, extracted from the ClimateNA model (Wang et al., 2016). We assessed the validity of this approach by comparing monthly ClimateNA outputs with local observations for the study period (January 2015-December 2018). Mean percent difference between measured and modelled monthly mean air temperatures and total precipitation over the period of record were $8.82 \pm 0.87 \%$ and $11.58 \pm 0.50 \%$, respectively. The model predicted mean monthly air temperatures well (linear regression: slope $=0.93, R^{2}=0.98$; Fig. S1) but tended to underpredict rainfall (slope $=0.70$, $R^{2}=0.76$; Fig. S2). However, rainfall is a notoriously difficult climate parameter to measure accurately, let alone model, and model estimates should improve over time with the incorporation of additional data sources. Given the fit statistics, we deemed the Climate NA model adequate for our purposes. Together, these data support the use of a modelderived climate normal for the region in the absence of 30 years of local measurements. Local temperature and precipitation anomalies were then compared to the Oceanic Niño Index (ONI, Climate Prediction Center, 2019) to assess the potential influence of Pacific Ocean basin-scale climate anomalies on local processes.

Bulk water samples were collected as grab samples from each of the seven streams. Samples for $\mathrm{NO}_{3}^{-}, \mathrm{PO}_{4}^{3-}$, $\mathrm{Si}(\mathrm{OH})_{4}$, and DOC were sampled as for the marine stations. At all freshwater stations, waters were also filtered with $0.45 \mu \mathrm{m}$ PES filters for ammonium $\left(\mathrm{NH}_{4}^{+}\right)$, total dissolved nitrogen (TDN), total dissolved phosphorus (TDP), and dissolved iron ( $\mathrm{dFe}$ ). Additional bulk water samples were collected in $50 \mathrm{~mL}$ centrifuge tubes for total nitrogen (TN) and total phosphorus (TP) and kept cool until analysis. These additional parameters are discussed separately from $\mathrm{NO}_{3}^{-}$, 
$\mathrm{Si}(\mathrm{OH})_{4}, \mathrm{PO}_{4}^{3-}$, and $\mathrm{DOC}$, in acknowledgement that analogous measurements were not taken in marine waters, except during the rainfall events (see below). This is the first time that nutrient concentrations have been reported for these watersheds. DOC concentrations from 2014-2016 were previously reported in Oliver et al. (2017) and St. Pierre et al. (2020a).

\subsubsection{Targeted stream samplings during rainfall events}

The streams were sampled during rainfall events to better understand how water chemistry changes along the rising and falling limbs of the hydrograph (Korver et al., 2019b). These high-frequency measurements are especially useful to train constituent flux models during high-flow events given that constituent concentrations often vary with discharge within a given watershed (Goñi et al., 2013).

During rainfall events, the streams were sampled using a combination of techniques: (1) opportunistic grab samples on the falling limb (all watersheds, 18 July 2015 to 15 November 2018); (2) a single-stage sampler (all watersheds, 21 to 25 July 2015 and 15 to 16 July 2017); and (3) an automated pump sampler (watershed 708 only, 17 to 27 September 2015 and 14 to 21 October 2017). The single-stage samplers were constructed by mounting $250 \mathrm{~mL}$ bottles at vertical increments above the low water level of the stream prior to each rain event. Vertical increments were adjusted depending on the weather forecast and predicted stage rise. As the water level rose, the bottles filled in sequence. Water exchange after filling was prevented by following the design of singlestage suspended-sediment samplers (Edwards and Glysson, 1999): two inverted stainless-steel U-shaped inlet tubes were inserted in the bottle through a rubber plug. The first inlet tube allows water to enter, and the second inlet tube, placed directly above the first, blocks water inflow by sealing the bottle's air exchange. Bottles were always completely filled at rising water levels, preventing river water from entering as water levels dropped. Additional information on the setup is included in the Supplement (see also Table S4).

\subsubsection{Freshwater plume samplings in nearshore waters}

To better understand the influence of rainfall events on nearshore environments, the plumes emanating from watersheds 819 and 703 were sampled during storms on $7 \mathrm{Au}$ gust and 19 September 2015, respectively (Fig. 1). Plume extent was first visually determined based on turbidity and water colour and finally by measuring the conductivity of surface waters in comparison to the Pruth marine station $\left(\sim 45000 \mu \mathrm{S} \mathrm{cm}^{-1}\right)$. Six sampling stations were then established across the plume and waters were sampled at 0,1 , and $5 \mathrm{~m}$ depth for all the same parameters as the streams, described above.

\subsection{Sample preparation and chemical analyses}

TP and TDP samples were preserved with $80 \mu \mathrm{L}$ of $95 \%$ $\mathrm{H}_{2} \mathrm{SO}_{4}$ and frozen until analysis. Samples for TN, TDN, $\mathrm{NH}_{4}^{+}, \mathrm{NO}_{3}^{-}$, and $\mathrm{Si}(\mathrm{OH})_{4}$ were frozen until analysis. Samples for TN, TDN, $\mathrm{NH}_{4}^{+}, \mathrm{NO}_{3}^{-}$(from August 2014 to June 2015), TP, TDP, and $\mathrm{PO}_{4}^{3-}$ (from August 2014 to June 2015) were analysed according to Canadian Association for Laboratory Accreditation (CALA)-certified protocols at the University of Alberta's Biogeochemical Analytical Service Laboratory (Table S2). From March 2015 onwards, $\mathrm{NO}_{3}^{-}, \mathrm{PO}_{4}^{3-}$, and $\mathrm{Si}(\mathrm{OH})_{4}$ were analysed at the University of British Columbia's Marine Zooplankton and Micronekton Laboratory. Dissolved inorganic nitrogen (DIN) and dissolved organic nitrogen (DON) were calculated as the sum of $\mathrm{NH}_{4}^{+}$and $\mathrm{NO}_{3}^{-}$and the difference between TDN and DIN, respectively. Dissolved cations, including $\mathrm{dFe}$, were preserved with $480 \mu \mathrm{L} 8 \mathrm{M} \mathrm{HNO}_{3}$ and kept cool until analysis by the Analytical Chemistry Services Laboratory (Ministry of Environment and Climate Change Strategy, Victoria, BC, Canada). Filtered DOC samples from freshwater and marine sites were preserved with $200 \mu \mathrm{L} 7.5 \mathrm{M} \mathrm{H}_{3} \mathrm{PO}_{4}$ or $6 \mathrm{M} \mathrm{HCl}$, respectively, and kept cool until analysis. Freshwater samples were analysed at the Analytical Chemistry Services Laboratory, while marine samples were analysed at the Ján Veizer Stable Isotope Laboratory (University of Ottawa, $\mathrm{ON}$, Canada). Instruments and detection limits for each constituent are summarised in Table S2.

\subsection{Freshwater biogeochemical inputs to the Kwakshua and Meay channels}

Freshwater inputs to the Kwakshua Channel system were quantified by relating constituent concentrations from both the routine monthly and targeted rainfall event samplings to 15 min discharge using log-linear models in the $\mathrm{R}$ package rloadest (Runkel et al., 2004; Runkel, 2013; Lorenz et al., 2015). For all watersheds except 708, models were constructed by relating discharge to concentration over the entire study period. At watershed 708, discharge monitoring began in August 2013 - 1 year earlier than elsewhere, so models were constructed for the entire period of record ( $9 \mathrm{Au}-$ gust 2013 to 31 December 2018). Daily flux estimates were, however, only made over the same period as for the other watersheds (1 August 2014 to 31 December 2018). According to convention (Analytical Methods Committee, 2001), half of the detection limit (see Table S2) was used for cases where concentrations of $\mathrm{NO}_{3}^{-}, \mathrm{NH}_{4}^{+}$, and $\mathrm{PO}_{4}^{3-}$ were flagged as below detection by the analytical labs. While we acknowledge the biases that this approach may introduce (Helsel, 2009), we believe it to be a best approximation of these low concentrations given the large number of parameters and sites presented here.

For each constituent and watershed, the best rloadest model was initially chosen to minimise Akaike's informa- 
tion criterion (AIC) and then assessed for goodness of fit using the bias percentage, partial load ratio (PLR; Stenback et al., 2011), and the Nash-Sutcliffe efficiency index ( $E$; Nash and Sutcliffe, 1970). Only the models for $\mathrm{NO}_{3}^{-}$consistently had an $E$ less than zero, indicating that the observed mean was a better predictor than the model estimates (Runkel et al., 2004; Lorenz et al., 2015; Runkel, 2013), and were therefore excluded from our analysis. Instead, the $\mathrm{NO}_{3}^{-}$flux was estimated by subtracting the $\mathrm{NH}_{4}^{+}$flux from the DIN flux on a given day. Mean $( \pm \mathrm{SE}, n=77)$ model $R^{2}$, bias percentage, PLR, and $E$ were $94.7 \pm 0.6,-0.76 \pm 0.85 \%$, $0.99 \pm 0.01$, and $0.78 \pm 0.03$, respectively. Constituent and watershed-specific model fit statistics are presented in Table S5. Errors reported on aggregate monthly or annual flux measurements were quantified by propagating the daily standard error of prediction, which incorporates the uncertainty of both the model fit and the load estimate.

\subsection{Other statistical considerations and analyses}

All statistical analyses were completed in R (R Core Team, 2019), using packages vegan (Oksanen et al., 2018), dplyr (Wickham et al., 2019), lme (Bates et al., 2015), and lsmeans (Lenth, 2016). Stoichiometric ratios were log-transformed prior to the calculation of summary statistics presented in figures in acknowledgement of the inherent non-normality of ratio data (Isles, 2020). Mean concentrations presented in figures and tables were then re-transformed to non-log scale to facilitate comparisons with literature values. Standard errors (SEs) are reported throughout, unless otherwise stated. The level of significance $(\alpha)$ was 0.05 but Bonferroni-corrected for cases when multiple comparisons were made. Statistics quantifying interannual variability utilise full calendar years only ( $n=4$, i.e., 2015-2018). Temperature and precipitation anomalies were compared to the ONI using Pearson's product moment correlation.

Differences in air temperature, rainfall, flow-weighted freshwater nutrient concentrations and fluxes, and marine nutrient concentrations across the period of record were assessed using linear mixed effects models, coding for year and month as fixed effects and watershed or station (marine) as a random effect. We chose to compare monthly flowweighted nutrient concentrations rather than point measurements to assess "true" temporal differences in concentration, independently of hydrology. Briefly, monthly flow-weighted nutrient concentrations were calculated by dividing the modelled monthly flux by the total monthly volume of water discharged by each stream. Tukey multiple comparisons were then assessed across all pairwise combinations of year and month; however, only interannual comparisons for a given month (e.g., July 2015 vs. July 2018) were deemed relevant for our purposes and are discussed.

Principal component analysis (PCA) was used to characterise the bulk chemistry of the freshwater inputs to the Kwakshua channel system. Prior to performing the PCA, flow-weighted molar concentrations of all chemical constituents were standardised using $Z$ scores to de-emphasise the very high DOC concentrations, which were typically 2 to 3 orders of magnitude greater than any other constituent.

\section{Results}

\subsection{Temperature and precipitation between 2014 and 2018}

Mean annual air temperature near sea level on the Calvert and Hecate islands over the study period was $8.73 \pm 0.12^{\circ} \mathrm{C}$ (full range: $-13.60-34.99^{\circ} \mathrm{C}$ ), similar to the $1981-2010$ normal for these watershed outlet sites $\left(8.93 \pm 0.20^{\circ} \mathrm{C}\right)$. Mean annual rainfall was $2790 \pm 61 \mathrm{~mm}$ (range: $2240-3520 \mathrm{~mm}$; $1981-2010$ normal $=2800 \pm 49 \mathrm{~mm}$ ) at these sites, increasing to $4312 \pm 106 \mathrm{~mm}$ at $1000 \mathrm{~m}$ elevation (1981-2010 nor$\mathrm{mal}=4620 \mathrm{~mm}$ ). Precipitation translated to a cumulative mean annual freshwater discharge to the Kwakshua Channel system of $0.174 \pm 0.055 \mathrm{~km}^{3}$ (Table 1, range: $0.161-$ $0.186 \mathrm{~km}^{3}$ ), equivalent to a mean annual specific runoff of $2500 \pm 790 \mathrm{~mm}$ (range: $2310-2670 \mathrm{~mm}$ ).

Rain $(\geq 0.2 \mathrm{~mm})$ was recorded at sea level between $63 \%$ and $69 \%$ of days in any given year (Table S6), and the region exhibited strong seasonality (Fig. 2a-c). Maximum and minimum monthly rainfall typically occurred in November and June, respectively (Fig. 2a). The longest (21-47 consecutive days with more than $0.2 \mathrm{~mm}$ of rain) and largest ( $>200 \mathrm{~mm}$ of rain, maximum $=567 \mathrm{~mm}^{\text {event }}{ }^{-1}$ ) rainfall events always occurred between November and March (Table S6). Maximum and minimum air and seawater temperatures occurred in July and December-February (Fig. 2b-c). The sampling period was characterised by dramatic fluctuations in the ONI, including strong El Niño (May 2015 to April 2016) and weak La Niña (October 2017 to March 2016) and El Niño (October to December 2018) events (Fig. 2d). Temperature and precipitation anomalies, though, were poorly correlated with the ONI (Fig. S3).

\subsection{Marine primary production and nutrient stoichiometry}

Chlorophyll $a$ concentrations ranged between $\sim 0.01$ and $14.67 \mu \mathrm{g} \mathrm{L}^{-1}$ (Fig. 3a). Based on chlorophyll $a$ concentrations, each year, primary production peaked between AprilJune and again in July-August (Fig. 3a). Mean marine $\mathrm{NO}_{3}^{-}$, $\mathrm{PO}_{4}^{3-}, \mathrm{Si}(\mathrm{OH})_{4}$, and DOC concentrations across the 0,1 , and $5 \mathrm{~m}$ depths were $8.18,0.78,18.67$, and $72.64 \mu \mathrm{mol} \mathrm{L}^{-1}$, respectively, but varied widely (Table $\mathrm{S} 7$ ). $\mathrm{NO}_{3}^{-}, \mathrm{PO}_{4}^{3-}$, and $\mathrm{Si}(\mathrm{OH})_{4}$ concentrations displayed strong seasonality but also interannual differences (Table 2; mixed effects models, $p<0.05$ on all terms, Table S8). Seasonal fluctuations in inorganic nutrient concentrations in marine waters were the opposite of chlorophyll $a$ concentrations: 
Table 1. Annual combined fluxes of nutrients from the seven gauged watersheds $\left(46.9 \mathrm{~km}^{2}\right)$, upscaled to the drainage area of the Kwakshua Channel system $\left(69.6 \mathrm{~km}^{2}\right)$, and mean $\pm \mathrm{SE}$ annual flow-weighted concentrations $\left(C_{\mathrm{F} . \mathrm{W} .}\right)$ based on the annual fluxes.

\begin{tabular}{|c|c|c|c|c|c|c|c|c|}
\hline \multirow[b]{2}{*}{ Year } & \multicolumn{4}{|c|}{$\begin{array}{c}\text { Flux } \\
\left(\mathrm{Mmol} \mathrm{yr}^{-1}\right)\end{array}$} & \multicolumn{4}{|c|}{$\begin{array}{c}C_{\mathrm{FFW}} \\
\left(\mu \mathrm{mol} \mathrm{L} \mathrm{L}^{-1}\right)\end{array}$} \\
\hline & 2015 & 2016 & 2017 & 2018 & 2015 & 2016 & 2017 & 2018 \\
\hline Water $\left(\mathrm{km}^{3}\right)$ & 0.172 & 0.186 & 0.179 & 0.161 & - & - & - & - \\
\hline DOC & $145 \pm 41$ & $156 \pm 44$ & $144 \pm 42$ & $129 \pm 37$ & $843 \pm 238$ & $837 \pm 235$ & $809 \pm 235$ & $800 \pm 228$ \\
\hline $\mathrm{TN}$ & $2.06 \pm 0.59$ & $2.30 \pm 0.65$ & $2.18 \pm 0.63$ & $1.88 \pm 0.54$ & $11.98 \pm 3.43$ & $12.37 \pm 3.51$ & $12.18 \pm 3.52$ & $11.69 \pm 3.33$ \\
\hline TDN & $1.83 \pm 0.44$ & $2.09 \pm 0.50$ & $1.96 \pm 0.48$ & $1.64 \pm 0.39$ & $10.64 \pm 2.56$ & $11.23 \pm 2.67$ & $10.96 \pm 2.66$ & $10.18 \pm 2.45$ \\
\hline DON & $1.70 \pm 0.42$ & $1.89 \pm 0.47$ & $1.79 \pm 0.45$ & $1.51 \pm 0.37$ & $9.86 \pm 2.43$ & $10.17 \pm 2.51$ & $10.03 \pm 2.53$ & $9.40 \pm 2.30$ \\
\hline DIN & $0.18 \pm 0.16$ & $0.20 \pm 0.19$ & $0.19 \pm 0.18$ & $0.17 \pm 0.15$ & $1.06 \pm 0.95$ & $1.09 \pm 1.03$ & $1.05 \pm 1.00$ & $1.04 \pm 0.95$ \\
\hline $\mathrm{NH}_{4}^{+}$ & $0.10 \pm 0.10$ & $0.14 \pm 0.16$ & $0.11 \pm 0.12$ & $0.06 \pm 0.07$ & $0.56 \pm 0.62$ & $0.73 \pm 0.83$ & $0.62 \pm 0.69$ & $0.39 \pm 0.45$ \\
\hline $\mathrm{NO}_{3}^{-}+\mathrm{NO}_{2}^{-\mathrm{a}}$ & $0.09 \pm 0.20$ & $0.07 \pm 0.25$ & $0.08 \pm 0.22$ & $0.10 \pm 0.17$ & $0.50 \pm 1.54$ & $0.36 \pm 1.86$ & $0.43 \pm 1.69$ & $0.65 \pm 1.40$ \\
\hline $\mathrm{Si}(\mathrm{OH})_{4}$ & $0.24 \pm 0.11$ & $0.24 \pm 0.11$ & $0.22 \pm 0.10$ & $0.21 \pm 0.10$ & $1.37 \pm 0.65$ & $1.28 \pm 0.59$ & $1.23 \pm 0.58$ & $1.30 \pm 0.61$ \\
\hline $\mathrm{TP}$ & $0.07 \pm 0.04$ & $0.08 \pm 0.05$ & $0.07 \pm 0.04$ & $0.06 \pm 0.04$ & $0.39 \pm 0.24$ & $0.42 \pm 0.25$ & $0.40 \pm 0.24$ & $0.38 \pm 0.23$ \\
\hline TDP & $0.05 \pm 0.03$ & $0.07 \pm 0.04$ & $0.06 \pm 0.03$ & $0.04 \pm 0.02$ & $0.30 \pm 0.16$ & $0.37 \pm 0.20$ & $0.34 \pm 0.18$ & $0.26 \pm 0.14$ \\
\hline $\mathrm{PO}_{4}^{3-}$ & $0.02 \pm 0.01$ & $0.01 \pm 0.01$ & $0.01 \pm 0.01$ & $0.01 \pm 0.01$ & $0.09 \pm 0.08$ & $0.07 \pm 0.07$ & $0.07 \pm 0.06$ & $0.08 \pm 0.08$ \\
\hline $\mathrm{Fe}$ & $0.69 \pm 0.21$ & $0.74 \pm 0.23$ & $0.66 \pm 0.21$ & $0.58 \pm 0.18$ & $4.00 \pm 1.23$ & $3.99 \pm 1.22$ & $3.72 \pm 1.17$ & $3.58 \pm 1.12$ \\
\hline \multicolumn{9}{|l|}{ Key ratios ${ }^{b}$} \\
\hline $\mathrm{NO}_{3}^{-}: \mathrm{Si}(\mathrm{OH})_{4}$ & $0.29 \pm 0.26$ & $0.18 \pm 0.54$ & $0.23 \pm 0.31$ & $0.39 \pm 0.22$ & - & - & - & - \\
\hline $\mathrm{NO}_{3}^{-}: \mathrm{PO}_{4}^{3-}$ & $5.00 \pm 0.27$ & $4.21 \pm 0.58$ & $5.36 \pm 0.35$ & $7.50 \pm 0.34$ & - & - & - & - \\
\hline $\mathrm{Si}(\mathrm{OH})_{4}: \mathrm{PO}_{4}^{3-}$ & $17.32 \pm 0.19$ & $23.34 \pm 0.20$ & $23.21 \pm 0.17$ & $19.25 \pm 0.21$ & - & - & - & - \\
\hline $\mathrm{Fe}: \mathrm{PO}_{4}^{3-}$ & $60.63 \pm 0.19$ & $81.10 \pm 0.21$ & $78.55 \pm 0.19$ & $61.57 \pm 0.20$ & - & - & - & - \\
\hline
\end{tabular}

${ }^{a} \mathrm{NO}_{3}^{-}+\mathrm{NO}_{2}^{-}$fluxes and $C_{\mathrm{F} . W}$. calculated as the difference between DIN and $\mathrm{NH}_{4}^{+} \cdot{ }^{\mathrm{b}}$ Key stoichiometric ratios calculated from monthly watershed-specific fluxes.

Table 2. Mean (range) annual nutrient concentrations (in $\mu \mathrm{mol} \mathrm{L}-1$ ) and stoichiometric ratios (mol mol ${ }^{-1}$ ) across the 13 marine stations in the Meay and Kwakshua channels.

\begin{tabular}{|c|c|c|c|c|c|c|c|c|}
\hline & 2015 & & 2016 & & 2017 & & 2018 & All \\
\hline Concentrations & & $n$ & & $n$ & & $n$ & & $n$ \\
\hline DOC & $70.86(7.87-965)$ & 365 & $77.69(34.47-606)$ & 70 & $96.14(63.95-131.28)$ & 28 & $105.82(59.02-198.89)$ & 16 \\
\hline $\mathrm{NO}_{3}^{-}+\mathrm{NO}_{2}^{-}$ & $8.10(0.01-22.39)$ & 526 & $11.83(0.01-20.35)$ & 136 & $7.75(0.02-22.07)$ & 108 & $9.58(0.02-19.64)$ & 34 \\
\hline $\mathrm{Si}(\mathrm{OH})_{4}$ & $19.14(0.12-40.70)$ & 535 & $23.58(1.30-34.34)$ & 135 & $16.56(0.04-39.64)$ & 108 & $19.75(0.11-33.90)$ & 33 \\
\hline $\mathrm{PO}_{4}^{3-}$ & 0.77 (< D.L. -2.50$)$ & 523 & $1.04(0.04-1.61)$ & 136 & $0.70(<$ D.L. -1.76$)$ & 103 & $0.86(0.01-1.50)$ & 33 \\
\hline \multicolumn{9}{|l|}{ Ratios } \\
\hline $\mathrm{NO}_{3}^{-}: \mathrm{Si}(\mathrm{OH})_{4}$ & $0.24(<0.01-2.30)$ & 526 & $0.32(<0.01-0.61)$ & 135 & $0.29(<0.01-1.09)$ & 108 & $0.40(0.08-4.01)$ & 33 \\
\hline $\mathrm{NO}_{3}^{-}: \mathrm{PO}_{4}^{3-}$ & $5.95(0.05-317)$ & 515 & $7.00(0.06-14.01)$ & 136 & $7.87(0.46-83.15)$ & 103 & $7.63(0.55-39.10)$ & 33 \\
\hline $\mathrm{Si}(\mathrm{OH})_{4}: \mathrm{PO}_{4}^{3-}$ & $11.19(0.76-1110)$ & 525 & $6.92(1.65-433)$ & 135 & $18.05(1.67-568)$ & 103 & $8.04(0.25-34.30)$ & 33 \\
\hline
\end{tabular}

the depletion of $\mathrm{NO}_{3}^{-}, \mathrm{PO}_{4}^{3-}$, and $\mathrm{Si}(\mathrm{OH})_{4}$ occurred annually in concert with the peak of primary production, followed by increases in concentration through the late summer and autumn as chlorophyll $a$ concentrations decreased (Fig. 3b-d). There was a 38-fold increase in surface $(0-5 \mathrm{~m})$ $\mathrm{NO}_{3}^{-}$concentrations between the monthly minimum (June mean: $0.54 \pm 0.10 \mu \mathrm{mol} \mathrm{L}^{-1}$ ) and maximum (December mean: $\left.20.78 \pm 0.16 \mu \mathrm{mol} \mathrm{L}{ }^{-1}\right)$. The same seasonal increase was 11-fold for $\mathrm{PO}_{4}^{3-}$ (June: $0.14 \pm 0.03 \mu \mathrm{mol} \mathrm{L}{ }^{-1}$; December: $1.58 \pm 0.02 \mu \mathrm{mol} \mathrm{L}^{-1}$ ) and 15 -fold for $\mathrm{Si}(\mathrm{OH})_{4}$ (June: $2.58 \pm 0.30 \mu \mathrm{mol} \mathrm{L}^{-1}$; December: $37.99 \pm 0.23 \mu \mathrm{mol} \mathrm{L}^{-1}$ ).
Mean DOC concentrations remained low throughout the year (Fig. 3e).

Mean $\mathrm{NO}_{3}^{-}: \mathrm{Si}(\mathrm{OH})_{4}, \mathrm{NO}_{3}^{-}: \mathrm{PO}_{4}^{3-}$, and $\mathrm{Si}(\mathrm{OH})_{4}: \mathrm{PO}_{4}^{3-}$ ratios were $0.3: 1,6: 1$, and $11: 1$, respectively. All ratios shifted seasonally (Fig. 4). $\mathrm{NO}_{3}^{-}: \mathrm{Si}(\mathrm{OH})_{4}$ and $\mathrm{NO}_{3}^{-}: \mathrm{PO}_{4}^{3-}$ reached a minimum in the summer (June-August) and increased again through the autumn and winter (September through February). $\mathrm{NO}_{3}^{-}: \mathrm{Si}(\mathrm{OH})_{4}$ was consistently below the Redfield-Brzezinski ratio for diatoms $(16: 15=0.94)$, oscillating between $<0.1$ between May and July and $\sim 0.6$ in January (Fig. 4a) and indicating an excess of $\mathrm{Si}(\mathrm{OH})_{4}$. 


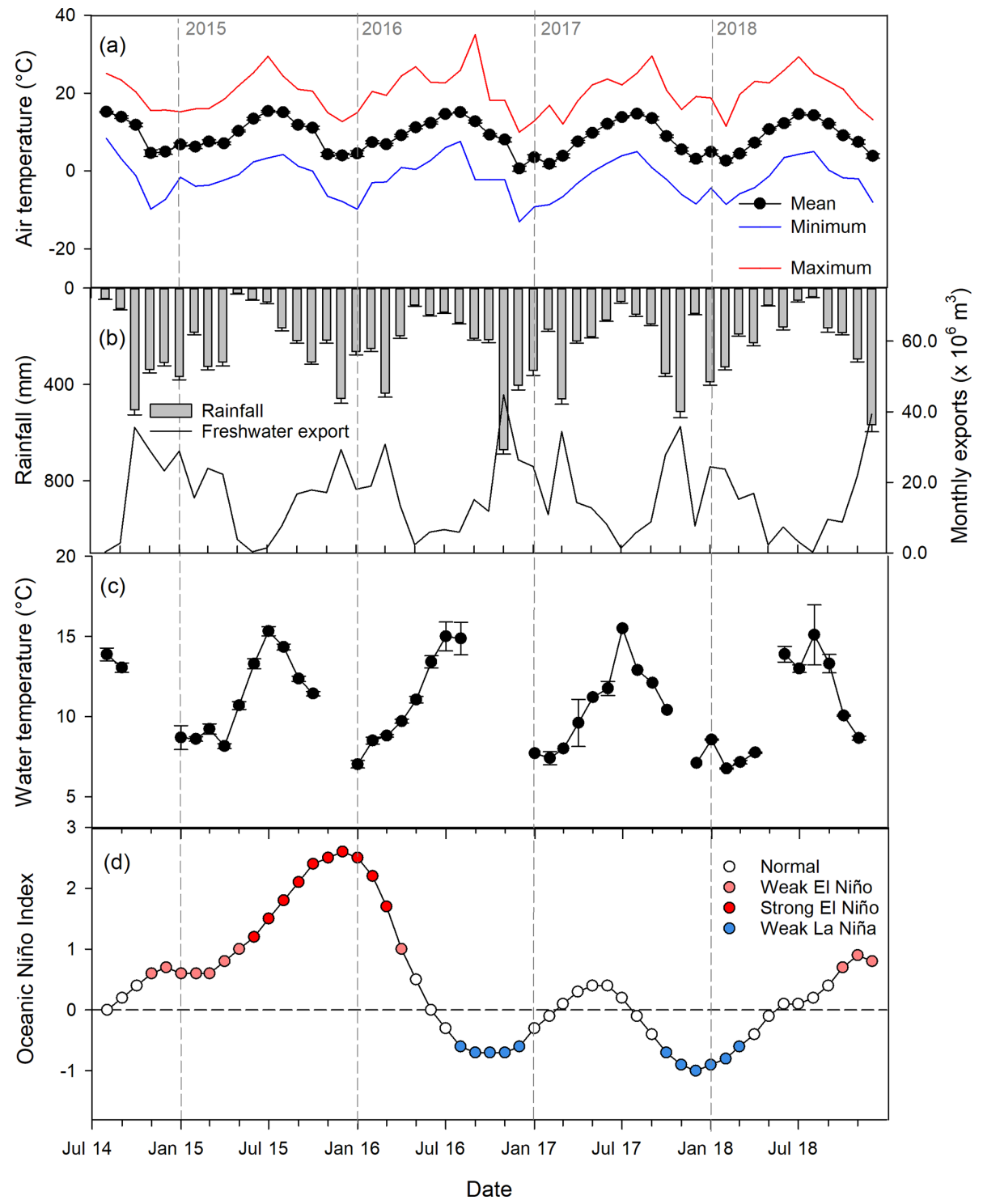

Figure 2. Climatology of the Calvert and Hecate islands over the study period (1 August 2014 to 31 December 2018): (a) monthly mean, minimum, and maximum air temperature across the seven watershed outlets; (b) mean monthly rainfall across the seven watershed outlets and total monthly discharge to the Kwakshua Channel system; (c) mean \pm SE surface water temperature at the marine stations during sampling events, measured using an YSI; (d) Oceanic Niño Index, with El Niño and La Niña events highlighted based on thresholds greater than \pm 0.5 (weak event) or greater than \pm 1.0 (strong event).

$\mathrm{NO}_{3}^{-}: \mathrm{PO}_{4}^{3-}$ consistently declined to $\sim 1: 1$ by July of each year and approached the Redfield ratio (16:1) during the winter months (Fig. $4 b) . \mathrm{Si}(\mathrm{OH})_{4}: \mathrm{PO}_{4}^{3-}$ ratios were close to or above the Redfield ratio (15:1) (Fig. 4c), with less of a discernible seasonal trend than for the other ratios. Greater variability between the stations was typically observed in the spring and summer months.

\subsection{Freshwater nutrient exports to nearshore waters of the NPCTR}

\subsubsection{Freshwater nutrient and DOC concentrations}

Mean measured concentrations of $\mathrm{NO}_{3}^{-}, \mathrm{PO}_{4}^{3-}, \mathrm{Si}(\mathrm{OH})_{4}$, and DOC in the streams were $0.48,0.11,1.67$, and $954 \mu \mathrm{mol} \mathrm{L}^{-1}$, respectively, and showed strong seasonal and spatial variability (Table S7). On average, measured concentrations of $\mathrm{NO}_{3}^{-}$, $\mathrm{PO}_{4}^{3-}$, and $\mathrm{Si}(\mathrm{OH})_{4}$ were $48 \pm 21(1.4-720), 9.87 \pm 1.20$ (0.62-28.15), and $12.42 \pm 1.43(0.25-28.6)$ times lower in fresh water than across the marine stations (Fig. 3b-d). 


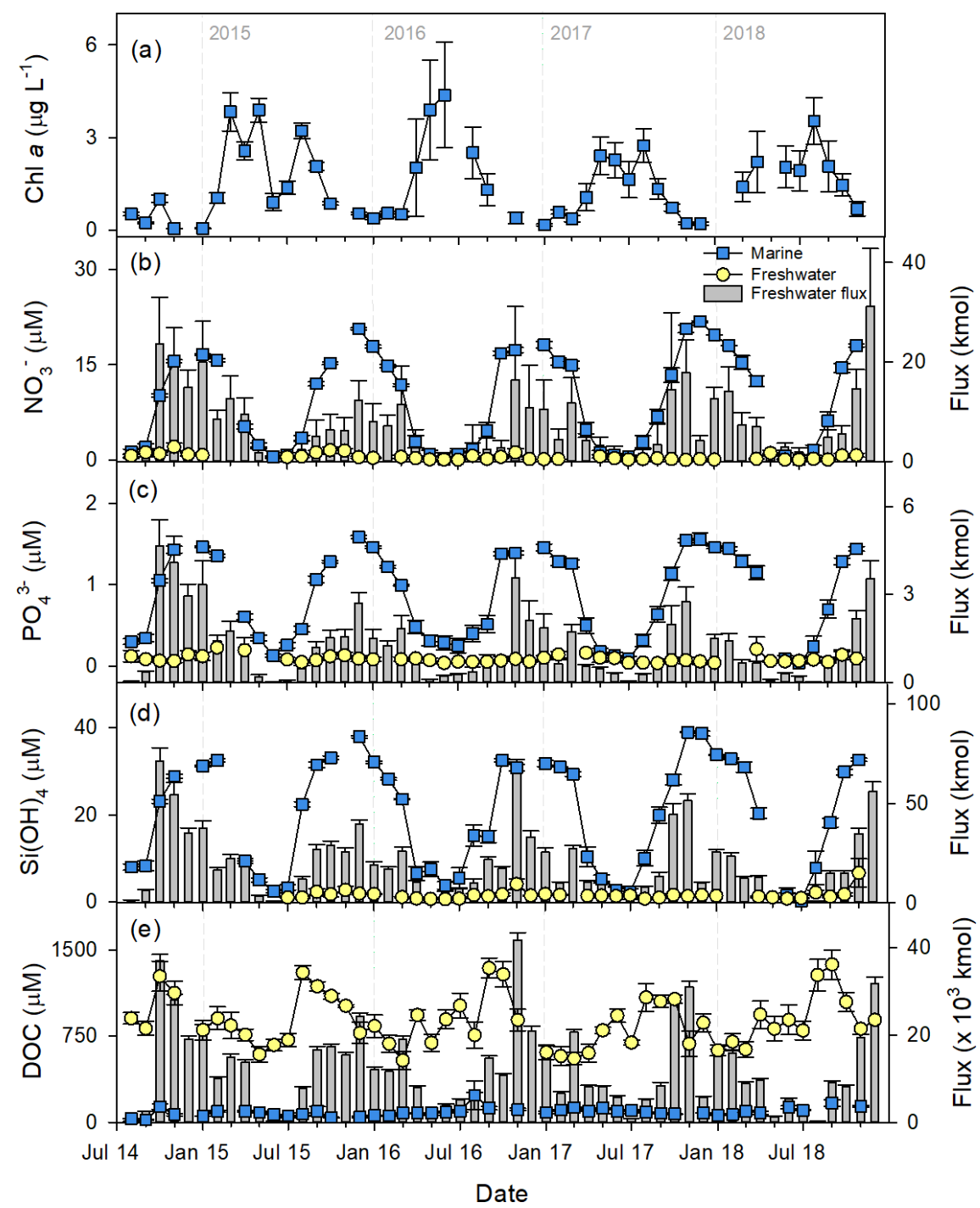

Figure 3. Time series of mean ( \pm SE) measured monthly chlorophyll $a(\mathbf{a})$, nutrient (b-d), and dissolved organic carbon (e) concentrations across both marine (mean of 0,1 , and $5 \mathrm{~m}$ depths) and freshwater stations. Freshwater fluxes to nearshore waters are also shown, upscaled from the measured fluxes to the entire drainage area of the Kwakshua Channel system. $\mathrm{NO}_{3}^{-}$, combined nitrate-nitrite; $\mathrm{Si}(\mathrm{OH})_{4}$, silicic acid; $\mathrm{PO}_{4}^{3-}$, orthophosphate; DOC, dissolved organic carbon.

The mean monthly concentrations of $\mathrm{PO}_{4}^{3-}$ and $\mathrm{Si}(\mathrm{OH})_{4}$ in fresh waters only exceeded those in marine waters on one occasion (July 2018). Seasonal variability in freshwater inorganic nutrient concentrations was muted, compared to marine waters (Fig. 3b-d). In contrast, freshwater concentrations of DOC were $14.55 \pm 0.99(6.98-36.29)$ times higher than in marine waters and exhibited high seasonal variability, increasing by almost 2 -fold between the low in February $\left(641 \pm 69.8 \mu \mathrm{mol} \mathrm{L}^{-1}\right)$ and the high in August $\left(1150 \pm 51.3 \mu \mathrm{mol} \mathrm{L}^{-1}\right.$; Fig. $\left.3 \mathrm{e}\right)$.

In general, flow-weighted inorganic nutrient concentrations were less than the measured concentrations, whereas flow-weighted organic nutrient concentrations were higher than the measured concentrations, reflecting the depen- dence of concentration on flow within the watersheds (Table S7). Although flow-weighted concentrations of DOC fluctuated seasonally (Fig. S4), this seasonal cycle was consistent between years (mixed effect model: only month term $p$ value $<0.05)$. $\mathrm{PO}_{4}^{3-}$ concentrations were approximately constant throughout the year ( $p$ value on all terms $>0.05$ ), while $\mathrm{NO}_{3}^{-}$and $\mathrm{Si}(\mathrm{OH})_{4}$ concentrations were variable across the period of record (year-month interaction $p<0.05)$ (Fig. S4).

Summary statistics for measured and flow-weighted concentrations of TN, TDN, DON, DIN, $\mathrm{NH}_{4}^{+}$, TP, TDP, and $\mathrm{dFe}$ are reported in Table S7. Flow-weighted concentrations of TN, TDN, DON, and dFe varied seasonally (linear mixed effects models: month term $p$ value $<0.05$; Table S9). As 


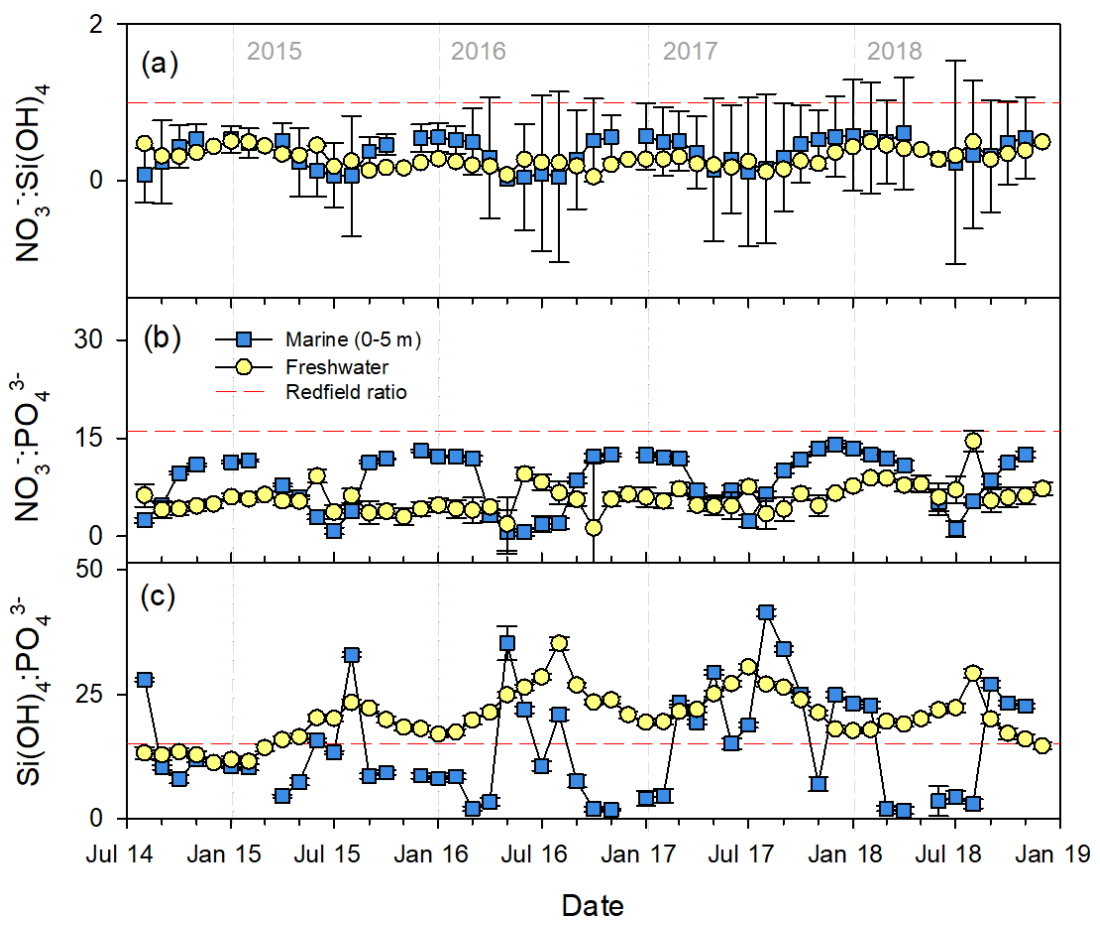

Figure 4. Time series of monthly mean $( \pm \mathrm{SE})$ stoichiometric ratios for $\mathrm{NO}_{3}^{-}: \mathrm{Si}(\mathrm{OH})_{4}(\mathbf{a}), \mathrm{Si}(\mathrm{OH})_{4}: \mathrm{PO}_{4}^{3-}(\mathbf{b})$, and $\mathrm{NO}_{3}^{-}: \mathrm{PO}_{4}^{3-}(\mathbf{c})$ across the marine (integrated $0-5 \mathrm{~m}$ ) and freshwater stations. Freshwater stoichiometric ratios are calculated from the monthly watershed-specific nutrient fluxes. Note that $\mathrm{SEs}$ are not shown on the freshwater $\mathrm{NO}_{3}^{-}: \mathrm{Si}(\mathrm{OH})_{4}$ ratios due to large variability that masks the seasonal pattern. The extended Redfield ratio is shown as a point of reference (red dashed line).

for $\mathrm{PO}_{4}^{3-}$, TP and TDP concentrations were approximately constant throughout the year. DIN and $\mathrm{NH}_{4}^{+}$concentrations were variable across the period of record (year-month interaction $p<0.05$ ). DIN concentrations were driven largely by a dramatic increase in concentration in August 2018 associated with $\mathrm{NO}_{3}^{-}$. Trends in $\mathrm{NH}_{4}^{+}$concentrations were also highly variable, with consistent interannual differences from August through December in 2015 (monthly means: $\left.0.778-0.827 \mu \mathrm{mol} \mathrm{L}^{-1}\right)$ and $2018\left(0.277-0.387 \mu \mathrm{mol} \mathrm{L}^{-1}\right)$. We note, however, that concentrations of the inorganic $\mathrm{N}$ species and all P species were often near or below detection.

\subsubsection{Freshwater nutrient fluxes, speciation, and stoichiometry}

DOC was by far the largest terrestrial input from the seven watersheds to the Kwakshua Channel system (mean $=143 \pm 20.4 ; 128$ to $156 \mathrm{Mmol} \mathrm{yr}^{-1}$; Table 1 ), exceeding all other inputs by 2 to 3 orders of magnitude. TN fluxes $\left(2.10 \pm 0.30 \mathrm{Mmol} \mathrm{yr}^{-1}\right)$ were overwhelmingly DON $(81.8 \pm 15.5 \%)$, with the remainder as DIN $(8.8 \pm 4.3 \%)$ or particulate $\mathrm{N}(\mathrm{PN}=\mathrm{TN}-\mathrm{TDN} ; 9.4 \pm 16.1 \%)$. Around half $(\sim 53.8 \%)$ of DIN was exported as $\mathrm{NH}_{4}^{+}$and the other half as $\mathrm{NO}_{3}^{-}$. TP exports were extremely low $\left(0.07 \pm 0.02 \mathrm{Mmol} \mathrm{yr}^{-1}\right)$, only $18.9 \pm 11.0 \%$ of which was as the readily available form $\mathrm{PO}_{4}^{3-}$, with the balance split between particulate phosphorus $(\sim 11 \%, \mathrm{PP}=\mathrm{TP}-\mathrm{TDP})$ and dissolved organic phosphorus $(\sim 63 \%$, DOP $=$ TP-PP$\mathrm{PO}_{4}^{3-}$ ).

Mean $\mathrm{NO}_{3}^{-}: \mathrm{Si}(\mathrm{OH})_{4}, \mathrm{NO}_{3}^{-}: \mathrm{PO}_{4}^{3-}$, and $\mathrm{Si}(\mathrm{OH})_{4}: \mathrm{PO}_{4}^{3-}$ ratios for freshwater fluxes were $0.27,5.40$, and 19.72, respectively (based on monthly watershed-specific fluxes). Mean monthly $\mathrm{NO}_{3}^{-}: \mathrm{Si}(\mathrm{OH})_{4}$ and $\mathrm{NO}_{3}^{-}: \mathrm{PO}_{4}^{3-}$ ratios were consistently at or below the Redfield ratio, although $\mathrm{NO}_{3}^{-}$: $\mathrm{Si}(\mathrm{OH})_{4}$ was highly variable (Fig. 4). Notably, $\mathrm{NO}_{3}^{-}: \mathrm{PO}_{4}^{3-}$ increased in the late summer. Stoichiometric ratios were, however, highly variable between the different watersheds (Fig. S5). Clear seasonal signals were difficult to discern across most watersheds, except for watersheds 703 and 708 . Watershed 703 in particular displayed late summer peaks across all ratios. $\mathrm{Fe}: \mathrm{PO}_{4}^{3-}$ far exceeded the extended Redfield ratio (0.01-0.1 : 1) across all watersheds (Fig. S5d) and fluctuated synchronously across most watersheds, driven by the late summer increases in Fe concentrations (Fig. S4).

\subsubsection{Freshwater yields of nutrients and DOC in a global context}

TN yields (378-463 $\mathrm{kg} \mathrm{km}^{-2} \mathrm{yr}^{-1}$ ) were at the low end of the global range $\left(1-20630 \mathrm{~kg} \mathrm{~km}^{-2} \mathrm{yr}^{-1}\right)$ but within the range for coniferous forests (Alvarez-Cobelas et al., 2008) (Table S10). Meanwhile, DON yields (304-381 kg km-2 $\mathrm{yr}^{-1}$ ) were at the high end of the estimated global range (10- 
$479 \mathrm{~kg} \mathrm{~km}^{-2} \mathrm{yr}^{-1}$; Alvarez-Cobelas et al., 2008), similar to recent measurements for other small forested NPCTR watersheds (229-401 kg km${ }^{-2} \mathrm{yr}^{-1}$; Fellman et al., 2021) but exceeding other estimated and modelled mean global and North American yields by up to 6-fold (Table S10). In contrast, DIN yields $\left(33.6-40.9 \mathrm{~kg} \mathrm{~km}^{-2} \mathrm{yr}^{-1}\right)$ were at the low end of the global ranges for $\mathrm{NO}_{3}^{-}$(Alvarez-Cobelas et al., 2008) but nearly identical to the mean value reported by Meybeck (1982). $\mathrm{Si}(\mathrm{OH})_{4}$ yields from the watersheds (84.5$95.7 \mathrm{~kg} \mathrm{~km}^{-2} \mathrm{yr}^{-1}$ ) were up to 26 times lower than the reported North American average (Dürr et al., 2011). Dissolved Fe yields $\left(462-596 \mathrm{~kg} \mathrm{~km}^{-2} \mathrm{yr}^{-1}\right)$ exceeded the estimated global riverine yield by between 55 and 710 times, depending on the estimate (De Baar and De Jong, 2001; Krachler et al., 2005). As previously described for a slightly different study period (Oliver et al., 2017), DOC yields (22 200$26900 \mathrm{~kg} \mathrm{~km}^{-2} \mathrm{yr}^{-1}$ ) exceeded by almost 2 times the upper bound of the global range $\left(2000-14000 \mathrm{~kg} \mathrm{~km}^{-2} \mathrm{yr}^{-1}\right)$ reported by Meybeck (1982) and exceeded by up to 18 and 26 times the modelled global and North American yields, respectively (Seitzinger et al., 2005) (Table S10), although our combined estimate was lower than that reported for the 2015 water year in Oliver et al. (2017) (33300 $\left.\mathrm{kg} \mathrm{km}^{-2} \mathrm{yr}^{-1}\right)$.

\subsubsection{Organic-matter-associated versus inorganic nutrients}

Measured TN, TDN, DON, and dFe concentrations pooled across all watersheds were positively correlated with DOC (Pearson product moment correlation, $r=0.612-0.738$, depending on the species; Table S11). Conversely, concentrations of DIN, $\mathrm{NH}_{4}^{+}, \mathrm{NO}_{3}^{-}$, TP, TDP, $\mathrm{PO}_{4}^{3-}$, and $\mathrm{Si}(\mathrm{OH})_{4}$ were only weakly positively $\left(r<0.300\right.$ for TP, TDP, $\mathrm{PO}_{4}^{3-}$, $\left.\mathrm{NH}_{4}^{+}, \mathrm{Si}(\mathrm{OH})_{4}\right)$ or negatively $(-0.300<r<0.000$ for DIN, $\mathrm{NO}_{3}^{-}$) associated with DOC. Based on these relationships, we distinguish hereafter between strongly-organic-matterassociated (DON - which makes up most of the TDN and $\mathrm{TN}$ pools - and $\mathrm{dFe}$ ) and inorganic (DIN, $\left.\mathrm{PO}_{4}^{3-}, \mathrm{Si}(\mathrm{OH})_{4}\right)$ nutrients in the freshwater pool. The strength and direction of these relationships were, however, highly watershed-specific (Table S11). This was especially true for $\mathrm{Si}(\mathrm{OH})_{4}$, for which watershed-specific correlation coefficients ranged between -0.15 and 0.60 . In particular, there was a strong positive correlation between concentrations of $\mathrm{Si}(\mathrm{OH})_{4}$ and $\mathrm{DOC}$ from watersheds 708 and 693 (Table S11), indicating the likely association with organic matter in those watersheds.

\subsubsection{Patterns in bulk freshwater chemistry}

We used PCA to describe the bulk freshwater chemistry independent of discharge over time using monthly flow-weighted DOC and nutrient concentrations. Two principal components (PCs) alone accounted for $63.8 \%$ of total observed variability. PC1, which accounted for $50.0 \%$ of total variability, was defined by TDN, TN, dFe, DON, DOC, $\mathrm{Si}(\mathrm{OH})_{4}$, and TP,
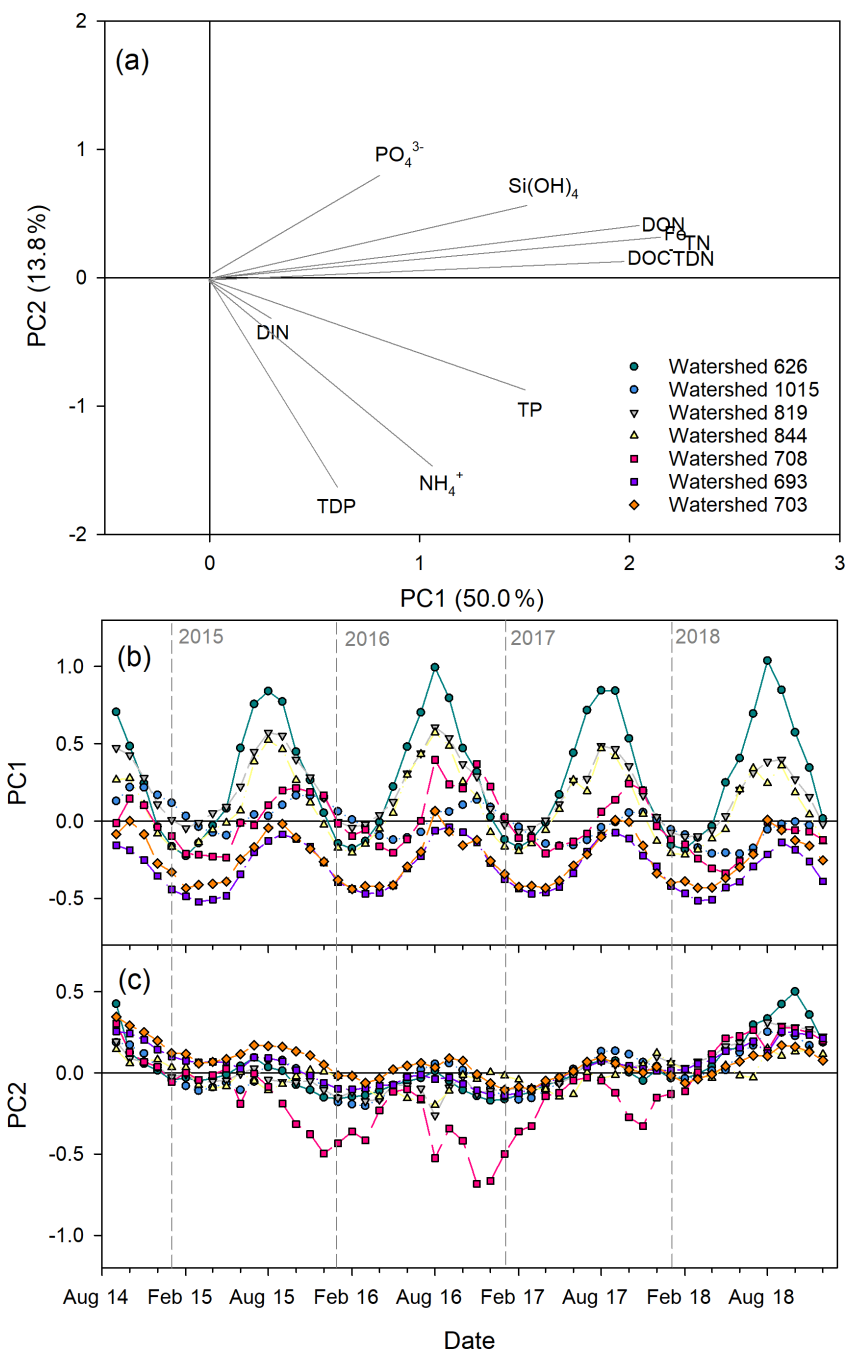

Figure 5. Principal component analysis of flow-weighted bulk freshwater chemistry exports to the nearshore environment. (a) $\mathrm{Nu}-$ trients in principal component (PC) space (scaled to preserve correlation between variables). Changes in PC1 (b) and PC2 (c) over time (scaled to preserve distance between objects). Note that PC1 loadings were multiplied by -1 to facilitate interpretation.

suggesting that it represented primarily dissolved organic matter (DOM)-associated compounds (Fig. 5a, Table S12). PC1 showed strong spatial separation between watersheds and seasonal variability over the period of record (Fig. 5b). Watersheds with the highest yields of DOC $(626,819$, 844; Oliver et al., 2017) also exported high concentrations of the DOM-associated suite of nutrients (TDN, TN, dFe, DON). Across most watersheds, loadings on PC1 were highest in June-July, indicating higher concentrations of DOMassociated compounds, reaching a minimum in FebruaryMarch. There was low interannual variability in PC1, suggesting a consistent seasonal export of DOM-associated nutrients from freshwater ecosystems. 
PC2 $(13.8 \%)$ was negatively associated with TDP, $\mathrm{NH}_{4}^{+}$, TP, and DIN but positively with $\mathrm{PO}_{4}^{3-}$ and $\mathrm{Si}(\mathrm{OH})_{4}$ and thus represented the inorganic nutrients (Fig. 5a). Like PC1, PC2 oscillated seasonally but was much more consistent between watersheds with the exception of watershed 708 (Fig. 5c; see Table S3 for watershed information). This pattern is reflective of the observed increases in concentrations of DIN, $\mathrm{NH}_{4}^{+}$, and TDP in the late winter/early spring and increases of $\mathrm{PO}_{4}^{3-}$ and $\mathrm{Si}(\mathrm{OH})_{4}$ in late summer/early autumn. Unlike $\mathrm{PC} 1$, there was some interannual variability in $\mathrm{PC} 2$.

\subsection{Mixing in nearshore waters}

Plume concentrations of $\mathrm{NO}_{3}^{-}, \mathrm{PO}_{4}^{3-}$, and $\mathrm{Si}(\mathrm{OH})_{4}$ were consistently higher than the freshwater reference concentrations during both rainfall events (Figs. 6, S6). Conversely, freshwater concentrations of DOC, DON, and $\mathrm{dFe}$ were much higher than in marine waters. During the August rainfall event (Fig. 6), all the surveyed nutrients (except for $\mathrm{DOC}$ ) mixed non-conservatively, with $\mathrm{NO}_{3}^{-}, \mathrm{PO}_{4}^{3-}$, and $\mathrm{dFe}$ mixing below conservative behaviour and $\mathrm{Si}(\mathrm{OH})_{4}$ and DON mixing above it. During the September 2015 event (Fig. S6), $\mathrm{NO}_{3}^{-}, \mathrm{PO}_{4}^{3}$, and $\mathrm{DOC}$ mixed approximately conservatively across most of the plume, whereas $\mathrm{Si}(\mathrm{OH})_{4}$ concentrations were well above conservative mixing, suggesting an additional source of $\mathrm{Si}(\mathrm{OH})_{4}$ to surface waters during the rain events. DON and $\mathrm{dFe}$ were below conservative mixing.

During both events, $\mathrm{NO}_{3}^{-}: \mathrm{Si}(\mathrm{OH})_{4}$ was below the Redfield ratio across the plume (Figs. 7, S7). $\mathrm{NO}_{3}^{-}: \mathrm{PO}_{4}^{3-}$ was above the Redfield ratio at lower salinities (5-10 salinity units) but approached the ratio across the rest of the plume during the September event (Fig. S7) and was well below the Redfield ratio across the whole plume except for one station in August (Fig. 7). $\mathrm{Fe}: \mathrm{PO}_{4}^{3-}$ and $\mathrm{Fe}: \mathrm{NO}_{3}^{-}$were close to the Redfield ratio across the plumes during both events.

\subsection{Role of inorganic freshwater nutrient inputs in subsidising nearshore productivity}

By scaling estimates of primary productivity measured at the nearby Rivers Inlet $\left(51.7^{\circ} \mathrm{N}, 127.3^{\circ} \mathrm{W}\right.$; Shiller, 2012) to the surface area of the Kwakshua Channel system, we previously estimated that total primary production is on the order of 21 to $42 \mathrm{Gg} \mathrm{Cyr}^{-1}$ (St. Pierre et al., 2020a). Assuming that phytoplankton nutrient requirements are at the extended Redfield ratio, freshwater $\mathrm{DIN}$ and $\mathrm{Si}(\mathrm{OH})_{4}$ exports from the small coastal watersheds of the Calvert and Hecate islands could, at most, directly support primary production on the order of $0.02 \mathrm{Gg} \mathrm{C} \mathrm{yr}^{-1}$, or less than $1 \%$ of the estimated total. Freshwater $\mathrm{PO}_{4}^{3-}$ fluxes likewise could only support up to $0.02 \mathrm{Gg} \mathrm{Cyr}^{-1}$ (based on the largest annual fluxes from 2016; Table 1). Assuming no loss, the freshwater $\mathrm{dFe}$ inputs could support between $7.3 \mathrm{Gg} \mathrm{C} \mathrm{yr}^{-1}$ (based on $\mathrm{P}: \mathrm{Fe}=0.1$ ) and $94.5 \mathrm{Gg} \mathrm{Cyr}^{-1}$ (based on $\mathrm{P}: \mathrm{Fe}=0.01$ ), or between $17.4 \%$ and $450 \%$ of the estimated primary produc- tion. However, given our observations (Fig. 6) and known $\mathrm{dFe}$ loss from the water column via flocculation and other processes, we fully acknowledge that these estimates represent a hypothetical upper bound on the possible stimulation of primary production by freshwater $\mathrm{dFe}$.

\section{Discussion}

We conducted routine monthly and targeted rainfall event surveys, linking marine-terminating streams and nearshore surface waters from August 2014 through to December 2018 to quantify the flux of terrestrial materials to nearshore ecosystems from small bog-forest watersheds with a hypermaritime climate. Below we discuss spatial and temporal variability of these fluxes and nutrient availability in receiving nearshore ecosystems, as well as the consequences of terrestrial exports for nearshore ecosystem function, and highlight priority research areas (Fig. 8).

\subsection{Decoupling of small hypermaritime watershed exports from wider-scale climate anomalies}

The relationship between short-term weather patterns along the northeast Pacific coast and the ONI has been well described, with El Niño events associated with warmer air temperatures and lower rainfall/stream flow, and La Niña events corresponding to colder and wetter periods (Ward et al., 2010). We did not, however, find this to be true at the scale of the Kwakshua Channel system, where air temperature and precipitation anomalies were unrelated to the ONI (Fig. S3). Whereas most work relating climate anomalies to stream flow has focused on large river basins (Wang et al., 2006) or continental scales (Ward et al., 2010), our results suggest that localised freshwater inputs from smaller hypermaritime watersheds of the NPCTR may be a more consistent input to nearshore surface waters. The small size of the study watersheds $\left(3.2-12.8 \mathrm{~km}^{2}\right)$ limits retention of precipitation, such that rain events directly translate into enhanced stream flows. That being said, ENSO events may have resulted in more intense storms or longer periods of low flow (Brigode et al., 2013), a temporal scale which was not specifically examined here.

In the marine environment, El Niño and La Niña events have been associated with changes in nutrient availability in the coastal northeast Pacific (Whitney and Welch, 2002). Intensification of stratification during El Niño events can lead to nutrient depletion in the surface ocean during the summer productive season (Whitney and Welch, 2002). Conversely, during La Niña events deeper mixing can favour higher nutrient concentrations in surface waters (Whitney and Welch, 2002). That there were no discernible interannual differences in nutrient availability in surface waters of the Kwakshua Channel system may have been due to a stronger influence of local oceanographic processes. 


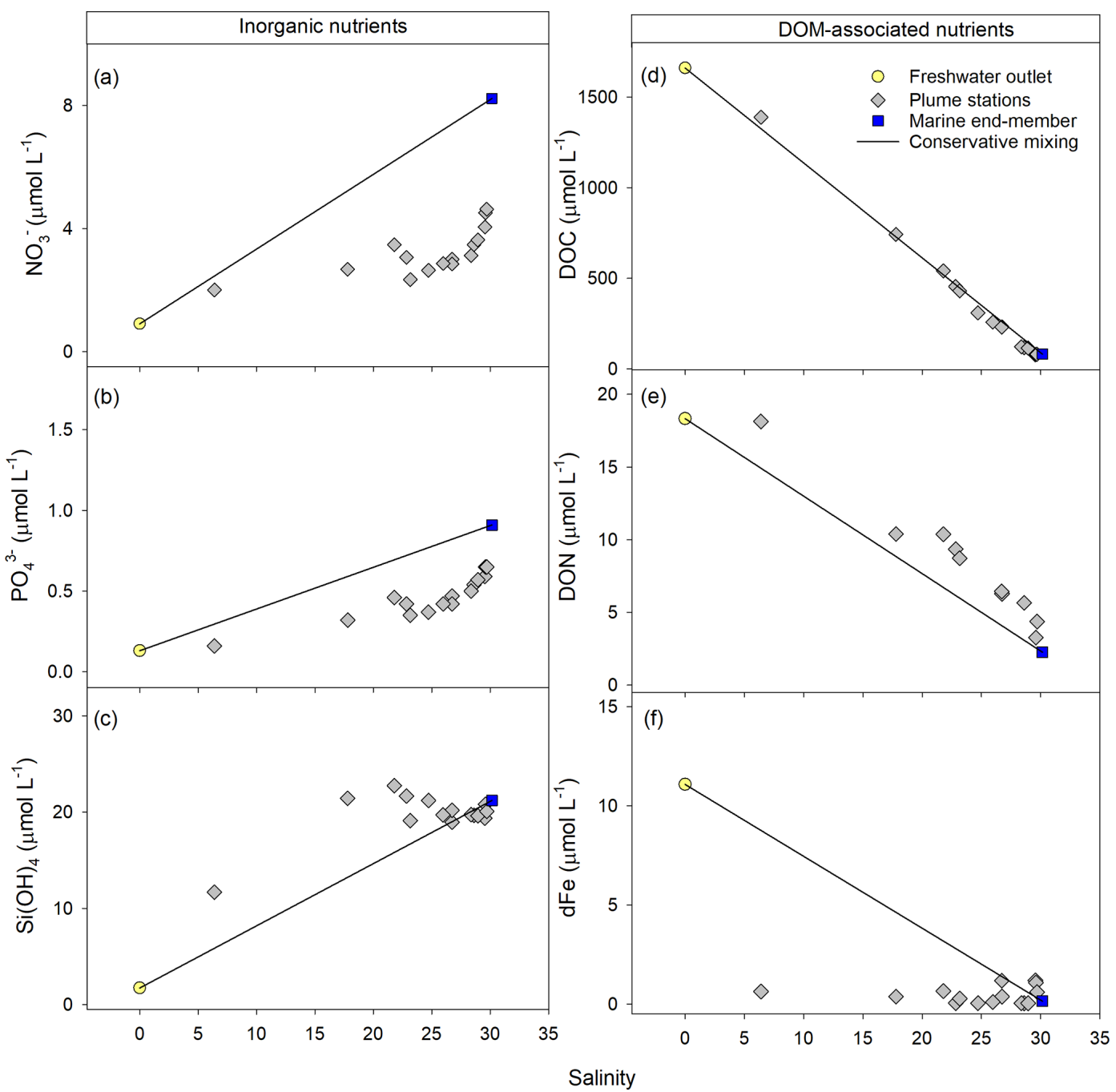

Figure 6. Nutrient concentration mixing plots across the freshwater plume $(0,1$, and $5 \mathrm{~m}$ at six stations) at the outlet of watershed 819 for the $86.8 \mathrm{~mm}$ rainfall event on 7 August 2015 (day 5 of $6 \mathrm{~d}$ event). Combined nitrate-nitrite $\left(\mathrm{NO}_{3}^{-}+\mathrm{NO}_{2}^{-} ; \mathbf{a}\right)$, orthophosphate $\left(\mathrm{PO}_{4}^{3-} ; \mathbf{b}\right)$, silicic acid $\left(\mathrm{Si}(\mathrm{OH})_{4} ; \mathbf{c}\right)$, dissolved organic carbon (DOC; d), dissolved organic nitrogen (DON; e), and dissolved iron (dFe; f) are shown. Freshwater and marine end-members are the mean concentration at watershed 819 for August 2015 and the plume sample with the highest salinity, respectively.

\subsection{Importance of freshwater exports for nearshore primary production}

\subsubsection{Origin of nutrients in freshwater systems of the NPCTR}

Nutrients in freshwater ecosystems of the NPCTR originate from a diverse array of potential sources, including soils and terrestrial ecosystems, interactions with the atmosphere, and the return of migratory fish species (Sugai and Burrell, 1984; Hood et al., 2007; Fellman et al., 2009c). Inorganic nitrogen species in fresh waters may originate from the fixation of atmospheric $\mathrm{N}_{2}$ or the ammonification of organic matter to $\mathrm{NH}_{4}^{+}$, with subsequent nitrification to $\mathrm{NO}_{3}^{-}$(Wetzel, 2001). On the other hand, $\mathrm{P}$ has a geologic source and is mobilised by mineral weathering, which releases $\mathrm{PO}_{4}^{3-}$, among other ions (Walker and Syers, 1976). However, the quartz diorite bedrock in the area is poor in P, with less than $0.2 \%$ of the mineral content accounted for by P-containing compounds (Roddick, 1996). The mineral P pool from which non-occluded $\mathrm{P}\left(\mathrm{PO}_{4}^{3-}\right.$ sorbed to $\mathrm{Fe}$ and aluminium oxides; Walker and Syers, 1976) can be mobilised is thus very small, such that remineralisation of organic material is likely to be the primary source of $\mathrm{P}$ in these watersheds. The small size of the watersheds and the large and frequent rainfall events characteristic of the NPCTR may limit in-watershed reprocessing of the large quantities of DOM, except in those few watersheds with larger lake and wetland areas (Oliver et al., 2017). Based on lithology (Hartmann and Moosdorf, 2012) and the hypermaritime boundary (Salkfield et al., 2016), we 


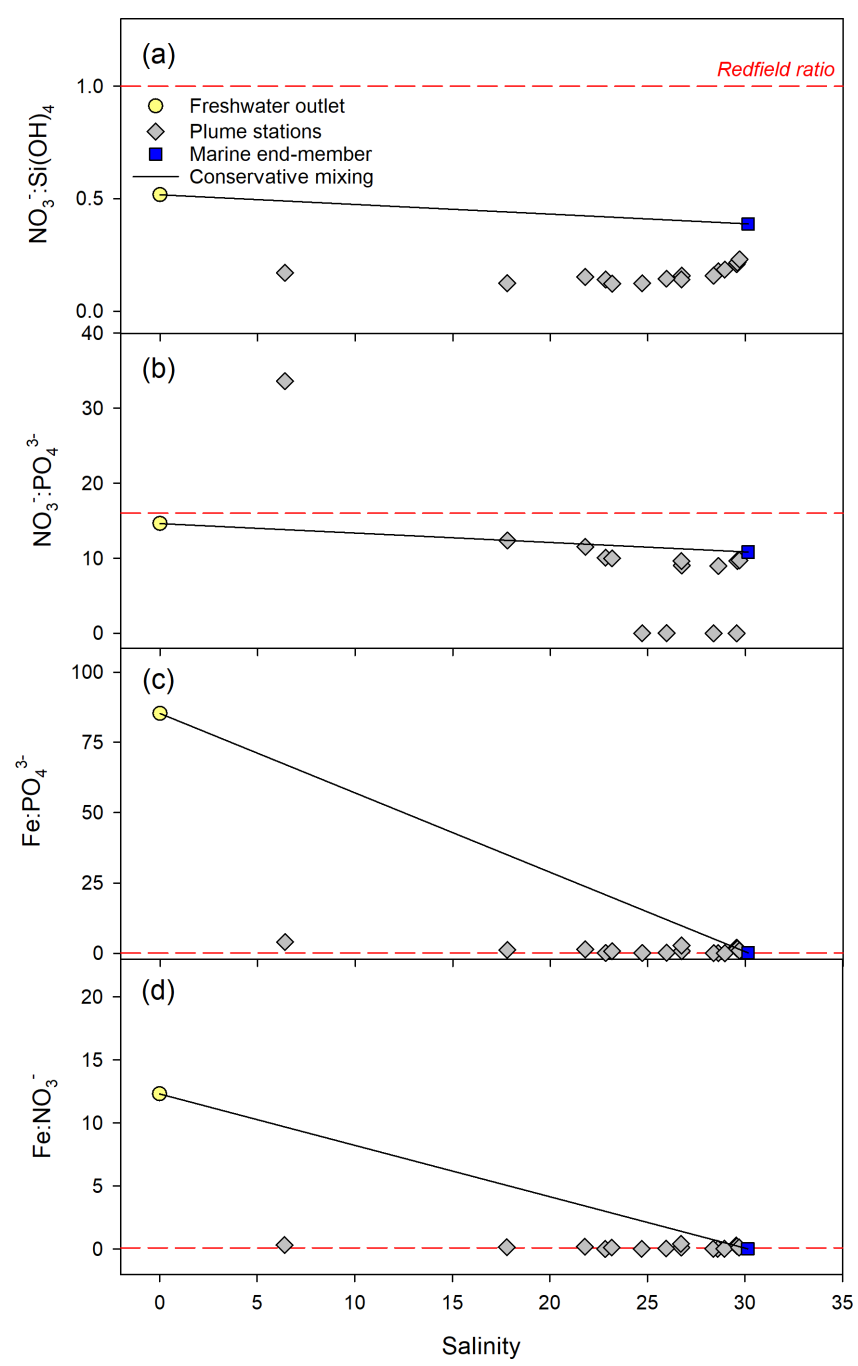

Figure 7. Stoichiometric ratios across the freshwater plume $(0$, 1 , and $5 \mathrm{~m}$ at six stations) at the outlet of watershed 819 during the rainfall event on 7 August 2015. Freshwater and marine endmembers are the mean concentration at watershed 819 for the month of August and the plume sample with the highest salinity, respectively.

determined that the bedrock of the Calvert and Hecate islands (acidic plutonic) is widespread on the BC outer coast, accounting for roughly $37 \%\left(11210 \mathrm{~km}^{2}\right)$ of the total area of the hypermaritime region $\left(30080 \mathrm{~km}^{2}\right)$. This suggests that low P fluxes are likely representative of many small coastal watersheds located within the NPCTR.

Concentrations of DOM-associated nutrients like DON and $\mathrm{dFe}$ increased seasonally following the end of the drier summer period (Fig. S4). This pattern is a well-known feature of transitional periods in highly seasonal catchments, including snow-covered catchments during the spring melt (Boyer et al., 1997) and in coastal catchments with distinct dry and wet seasons, like those sampled here (Sanderman et al., 2009; Oliver et al., 2017; Fellman et al., 2009a). When hydrological connectivity is low between soils and streams during drier periods, DOM accumulates in soils, a by-product of microbial degradation of organic matter. With the onset of autumn rains, the accumulated DOM is then flushed into streams. This transition is also associated with a change in the source and therefore lability of the DOM, discussed in detail for these watersheds in Oliver et al. (2017). dFe in particular may be subject to dissolution by organic acids at the end of the summer (Ling Ong et al., 1970; Keller, 2019), and the resultant $\mathrm{Fe}-\mathrm{OM}$ complexes can then be exported to streams and rivers (Jones, 1998; Boyer et al., 1997). In a similar vein, ratios involving $\mathrm{NO}_{3}^{-}$also consistently showed increased relative $\mathrm{NO}_{3}^{-}$concentrations in July and/or August in each year (Fig. 4). We surmise that this may be due to increased remineralisation of DOM coupled with the oxygenation of previously waterlogged soils during the dry summer months.

The seasonal increase in concentrations of the DOMassociated nutrients was also observed for $\mathrm{Si}(\mathrm{OH})_{4}$, albeit to a lesser extent and with high spatial variability (Fig. S4). Dissolved $\mathrm{Si}(\mathrm{OH})_{4}$ presence in freshwater systems is largely a function of local geology. Its availability is subsequently determined by a number of factors, including DOM concentration and quality, internal processing in lakes and streams (e.g., redox cycling, phytoplankton uptake), water temperature, and $\mathrm{pH}$ (Wetzel, 2001). $\mathrm{Si}(\mathrm{OH})_{4}$ concentrations in the streams were highly variable, and the origin of $\mathrm{Si}(\mathrm{OH})_{4}$ is not obvious. When pooled across all samples, $\mathrm{Si}(\mathrm{OH})_{4}$ was unrelated to DOC (Table S11). For certain watersheds, though, $\mathrm{Si}(\mathrm{OH})_{4}$ was strongly positively correlated with DOC $(r>$ 0.50 for watersheds 708 and 693), suggesting that $\mathrm{Si}(\mathrm{OH})_{4}$ there was associated with DOM. However, there was no relationship or even a weak negative one for others (Table S11). The highest concentrations of $\mathrm{Si}(\mathrm{OH})_{4}$ were consistently observed in watersheds 703 and 626 and were unrelated to DOC, suggesting that deposits of fine sediments found within both watersheds may support greater mineral weathering (Eamer and Shugar, 2015). Given the low Si concentrations in streams of Calvert and Hecate Island and their similarity to marine waters, it appears that there is little, if any, influence of freshwater $\mathrm{Si}(\mathrm{OH})_{4}$ exports over the Kwakshua Channel system as a whole.

\subsubsection{Role of freshwater nutrient inputs in nearshore ecosystems}

Our results suggest that freshwater inputs of most inorganic nutrients (DIN, $\mathrm{PO}_{4}^{3-}$ ) can directly support less than $1 \%$ of the estimated primary production in nearshore surface waters in this particular area of the NPCTR. In many cases, terrestrial DOM-associated nutrients are not directly available to phytoplankton in nearshore waters, and their incorporation into food webs first requires a mineralisation step (Eppley and Peterson, 1979; Hedges et al., 1997), or cleavage by exoenzymes (Benitez-Nelson, 2000). Our earlier work in 


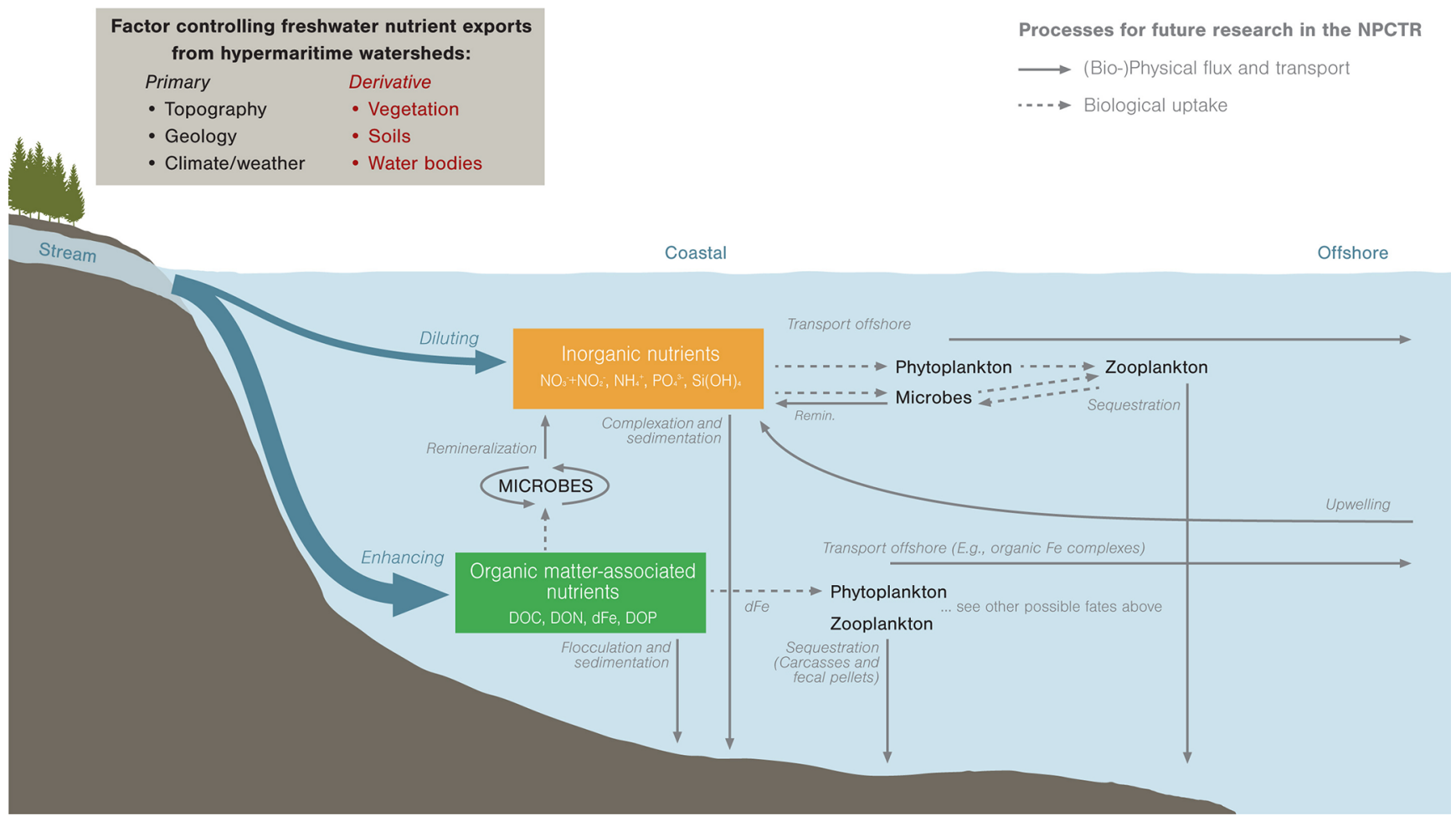

Figure 8. Conceptual framework highlighting nutrient dynamics in coastal waters downstream of watersheds dominated by bog forests of the NPCTR. The size of arrows shows the relative magnitude of these processes (if known). Grey arrows indicate fluxes that are poorly quantified in this region.

the Kwakshua Channel system suggested that large inputs of DOM during rainfall events may favour microbial growth in surface waters (St. Pierre et al., 2020a), which could enhance remineralisation. Indeed, in the Baltic Sea, increasing terrestrial inputs have been associated with a shift from largely autotrophic communities to increasing heterotrophy in surface waters (Wikner and Andersson, 2012). Studies in estuaries around the world have also highlighted the potential role of terrestrial DOM in subsidising marine zooplankton production (Hoffman et al., 2008; Hitchcock et al., 2016), though the extent to which that is the case here is unknown (Fig. 8).

The fact that concentrations of key inorganic nutrients (DIN, $\mathrm{PO}_{4}^{3-}, \mathrm{Si}(\mathrm{OH})_{4}$ ) in fresh waters feeding the Kwakshua Channel system are consistently lower than in adjacent marine waters is unusual (Wetz et al., 2006), albeit not unheard of along the eastern Pacific coast (Cuevas et al., 2019). In the remote fjords of southern Chile, low-salinity waters have been associated with lower concentrations of $\mathrm{NO}_{3}^{-}$and $\mathrm{PO}_{4}^{3-}$ but higher concentrations of $\mathrm{Si}(\mathrm{OH})_{4}$ than higher-salinity waters (Cuevas et al., 2019). While riverine inputs were not explicitly measured, this suggests that freshwater inputs may act to dilute inorganic nutrient pools in marine surface waters in southern Chile, as in the Kwakshua Channel system. To date, many of the measurements spanning the land-to-ocean aquatic continuum have been made in waters flowing through heavily-human-impacted watersheds (e.g., Baltic Sea, Mississippi River/Gulf of Mexico). Agricultural, industrial, and large urban development in these watersheds tends to increase freshwater inorganic nutrient delivery to coastal waters (e.g., Perez et al., 2011). Our results highlight the need to study less intensively disturbed regions to gain a better global understanding of nutrient and carbon dynamics at the land-ocean interface.

Ratios of potentially limiting nutrients in marine waters consistently indicated $\mathrm{N}$ limitation relative to $\mathrm{Si}$ and $\mathrm{P}$ in nearshore waters (Figs. 4, 7, S7). This suggests that (a) there is an additional source of nutrients - especially $\mathrm{N}$ - potentially unaccounted for, (b) phytoplankton nutrient requirements in these waters deviate from Redfield quantities, or (c) phytoplankton experience replete growth until the limiting nutrient had been consumed. In support of the first, DON fluxes from the Calvert and Hecate islands were high, with concentrations exceeding those in marine waters during the rainfall events (Figs. 6e, S6e). DON may be an additional source of DIN to surface waters through remineralisation and/or photochemical decomposition processes (Eppley and Peterson, 1979; Goldman et al., 1987). In Arctic coastal waters, for example, it is estimated that microbes incorporate at least $74.6 \%$ of the nitrogen that they consume, with DIN regeneration accounting for up to the remaining $25.4 \%$ (Tank et al., 2012). This, combined with photoammonification, may result in total DIN regeneration rates from terrestrial DON 
inputs of between $55 \%$ and $83 \%$ (Tank et al., 2012). By applying these potentials to the freshwater DON fluxes from the Calvert and Hecate islands, we estimate that between 0.83 and $1.57 \mathrm{Mmol} \mathrm{yr}^{-1} \mathrm{DIN}$ could originate from first-order regeneration of the terrestrial DON flux, effectively increasing the terrestrially derived inorganic nitrogen pool by 5 to 8 times. Unlike Arctic coastal areas, NPCTR watersheds are heavily forested and not underlain by permafrost, and coastal northeast Pacific waters are often - though not always - less turbid than their Arctic counterparts. These estimates should consequently be considered very preliminary. In the Baltic Sea, nitrogen regeneration can support between $78 \%$ and $97 \%$ of primary production in coastal waters (Klawonn et al., 2019), while in other coastal areas, nitrogen regeneration can more than ( $>100 \%)$ satisfy $\mathrm{N}$ demand by phytoplankton (Diaz and Raimbault, 2000). Indeed, recent estimates suggest that terrestrial nitrogen can be recycled seven times before being lost from coastal Arctic waters (Terhaar et al., 2021), highlighting the importance of regeneration in coastal waters. Detailed marine nitrogen species profiles and local estimates of nitrogen uptake and regeneration would, however, be valuable to understand the importance of organic nitrogen in these waters (Fig. 8). Higher summertime phytoplankton growth in the nearshore waters of Prince William Sound (Gulf of Alaska) is believed to be principally sustained by regenerated nitrogen from both terrestrial and marine sources (Strom et al., 2006), suggesting that some phytoplankton communities along the NPCTR coast may be particularly well adapted to or closely associated with microbes capable of the rapid remineralisation of organic-matter-associated nutrients.

Alternatively, phytoplankton nutrient requirements may deviate from Redfield quantities, such that the use of Redfield ratios is imperfect in this region. Local or regional deviations from Redfield stoichiometry in surface waters have been widely reported (Körtzinger et al., 2001; Martiny et al., 2013). Though not accounting for $\mathrm{Si}$ or Fe, the $\mathrm{C}: \mathrm{N}: \mathrm{P}$ ratio of phytoplankton declines with increasing latitude, with a mean $\mathrm{C}: \mathrm{N}: \mathrm{P}$ of $78: 13: 1$ in nutrient-rich high-latitude $\left(45\right.$ to $65^{\circ} \mathrm{N}$ ) waters (Martiny et al., 2013). The mean water column $\mathrm{N}: \mathrm{P}\left(\mathrm{NO}_{3}^{-}: \mathrm{PO}_{4}^{3-}\right)$ ratio in the marine surface waters along the Central Coast was $6: 1$ but fluctuated annually between $\sim 1: 1$ in mid-summer and the Redfield ratio of $16: 1$ in the winter (Fig. 4c). In the Gulf of Alaska, Strom et al. (2006) observed similar but less dramatic seasonal changes in $\mathrm{NO}_{3}^{-}: \mathrm{PO}_{4}^{3-}$ through the productive spring and early summer months in the inner shelf waters. As in the Kwakshua Channel system, waters along the outer shelf of the Gulf of Alaska were also characterised by an excess of $\mathrm{Si}(\mathrm{OH})_{4}$ relative to $\mathrm{NO}_{3}^{-}$, conditions which were associated with the proliferation of small $(<5 \mu \mathrm{m})$, non-diatomaceous cells. Although we did not characterise phytoplankton communities as part of this study, excess $\mathrm{Si}(\mathrm{OH})_{4}$ in surface waters could indicate that diatom production may be limited by $\mathrm{NO}_{3}^{-}, \mathrm{dFe}$, or another nutrient altogether.
Like DON, concentrations of $\mathrm{dFe}$ in fresh waters greatly exceeded those in marine surface waters, corresponding to high fluxes of potentially limiting $\mathrm{dFe}$ to the coastal environment. $\mathrm{dFe}$ mixed well below conservative behaviour across both freshwater plumes (Figs. 6f, S6f), suggesting either the rapid sedimentation of $\mathrm{dFe}$ out of surface waters, a fraction that may occur with the flocculation of DOC (St. Pierre et al., 2020a; Herzog et al., 2020a), or the rapid uptake of dFe into food webs. While Fe limitation has previously been documented for diatoms in nearshore coastal waters of the North Pacific (Takeda, 1998; Bruland et al., 2001), primary productivity was not explicitly measured in this study, thus limiting the direct conclusions that can be drawn without additional data.

Fe availability to both microbes and higher trophic level organisms across the global oceans depends on the presence and identity of organic ligands to which $\mathrm{Fe}$ binds (Lauderdale et al., 2020). Terrestrial dissolved organic-matter-bound Fe, which likely predominates in these watersheds, has been shown to be highly stable during estuarine mixing and can be transported well beyond the estuary to open waters where it can serve as a source of potentially limiting $\mathrm{Fe}$ (Herzog et al., 2020b). However, despite this stability, these complexes remain permeable to microbial siderophores (Batchelli et al., 2010), molecules with a strong affinity for Fe that are produced by microbes across a wide diversity of nutrient regimes in the coastal oceans (Boiteau et al., 2019). The quantification of $\mathrm{dFe}$ complexation and more broadly of fate (sedimentation, uptake) is an important next step within this region (Fig. 8).

\subsubsection{Spatial and temporal variability in nearshore mixing}

There are several possible reasons why the mixing of $\mathrm{NO}_{3}^{-}$, $\mathrm{PO}_{4}^{3-}$, and $\mathrm{DON}$ varied between the two rainfall events (Figs. 6, S6). Firstly, the plumes sampled emanated from two different watersheds (819 on 7 August and 703 on 19 September), which have among the highest and lowest organic carbon yields of the study watersheds, respectively (Oliver et al., 2017). Because the quality and quantity of the freshwater exports differ so dramatically, some of the differences observed in mixing may reflect differences in the freshwater end-member. The outlet stream of watershed 819 drains extensive wetlands (50.2\% watershed area; Table S3), ecosystems known to be hotspots of DOM production and processing. On the other hand, watershed 703 has the thickest mineral soils (mean depth $=35.8 \mathrm{~cm}$; Oliver et al., 2017), exposed bedrock at high elevation, a steep watershed gradient, and comparatively low coverage by lakes and wetlands, indicating little time for retention and processing of nutrients within the watershed before export to coastal waters. We note, however, that the freshwater end-members, while watershed- and month-specific, were not sampled at the same time as the plume and may therefore not accurately 
reflect nutrient concentrations during these specific rainfall events (see also Fig. 3 for variation in the freshwater endmember). Secondly, the sampling time within each of the respective events was quite different. The sampling in August occurred on the fifth day of a $6 \mathrm{~d}$ storm during a drier period, with rainfall of $\sim 62 \mathrm{~mm}$ up to and including sampling on 7 August (total rainfall of $\sim 85 \mathrm{~mm}$ over $6 \mathrm{~d}$, previous $30 \mathrm{~d}$ total $=\sim 100 \mathrm{~mm}$ ). In contrast, the September sampling occurred on the second day of an $8 \mathrm{~d}$ event, with rainfall of $\sim 49 \mathrm{~mm}$ up to and including sampling on 19 September (total rainfall of $\sim 135 \mathrm{~mm}$ over $8 \mathrm{~d}$, previous $30 \mathrm{~d}$ to$\mathrm{tal}=\sim 190 \mathrm{~mm}$ ). Rainfall events of these durations and sizes are among the most common in any given year (Table S6), and as such these events were representative of mediumsized events during the warmer seasons. Finally, these events occurred at different times of year within the context of the seasonal marine cycle: one in early August when temperatures are still warm and marine waters are still relatively productive, and the second in mid-September when the transition to lower productivity and cooler/rainier weather has typically begun. For example, $\mathrm{NO}_{3}^{-}$exhibited non-conservative behaviour during the August event when we would expect uptake by primary producers to be higher (Fig. 6) but conservative behaviour during the September event (Fig. S6) when primary production is somewhat lower. Regardless of the reason(s), these two events highlight the variable relationship between nearshore waters and freshwater inputs over time and space.

\subsubsection{Nutrients across the land-ocean interface in the NPCTR}

While DOC has been a major focus across the NPCTR (see Fellman et al., 2009a; Hood et al., 2006; Oliver et al., 2017; and references therein), we know relatively little about nutrient stoichiometry across the land-to-ocean aquatic continuum in this region. A handful of studies documenting nutrients in either coastal waters or streams exist, without full consideration of the composition of the adjacent waters. A notable exception to this, but outside the NPCTR of North America, includes efforts in three coastal temperate rainforest watersheds along the eastern coast of Japan. In contrast to our findings, freshwater concentrations of $\mathrm{NO}_{3}^{-}$ $\left(18-46 \mu \mathrm{mol} \mathrm{L}^{-1}\right)$ and $\mathrm{Si}(\mathrm{OH})_{4}\left(44-172 \mu \mathrm{mol} \mathrm{L}^{-1}\right)$ were higher than in nearshore waters $\left(\mathrm{NO}_{3}^{-}=0.7-22 \mu \mathrm{mol} \mathrm{L}-1\right.$; $\left.\mathrm{Si}(\mathrm{OH})_{4}=10-109 \mu \mathrm{mol} \mathrm{L}^{-1}\right)$, such that fresh waters may have acted as sources of these nutrients to adjacent marine systems (Matsunaga et al., 1998). Marine surveys of freshwater plumes along the Oregon coast likewise inferred that coastal watersheds were important sources of $\mathrm{NO}_{3}^{-}(43-52 \mu \mathrm{mol} \mathrm{L}-1), \mathrm{PO}_{4}^{3-}\left(4.9-5.5 \mu \mathrm{mol} \mathrm{L}^{-1}\right), \mathrm{Si}(\mathrm{OH})_{4}$ $\left(171-197 \mu \mathrm{mol} \mathrm{L}^{-1}\right)$, and $\mathrm{dFe}\left(0.12 \mu \mathrm{mol} \mathrm{L}^{-1}\right)$ to nearshore waters (Wetz et al., 2006). However, in both Oregon and Japan, the studied watersheds include agricultural activities, large human settlements, and more productive forests with
$\mathrm{N}$-fixing alder, all of which tend to increase nutrient loadings to aquatic ecosystems. In both cases, these surveys were also conducted over short time periods (1-2 months) and may therefore not represent the full range of possible conditions.

The nutrient and DOC concentrations/yields that we observed in the Calvert and Hecate streams were very similar to those from earlier work in the Wilson and Blossom rivers (Sugai and Burrell, 1984) and the Peterson Creek watershed of southeast Alaska (Fellman et al., 2021). In the Wilson and Blossom rivers, synchronous late summer/early autumn spikes in DOC and $\mathrm{Fe}$ concentrations were attributed to the flushing of forest soils following the drier summer period. A late summer peak in $\mathrm{NH}_{4}^{+}$and $\mathrm{PO}_{4}^{3-}$ concentrations was associated with the large salmon runs supported by the rivers (Sugai and Burrell, 1984). Although the streams of Calvert and Hecate do not support large salmonid stocks, we did observe a small increase in flow-weighted $\mathrm{NH}_{4}^{+}$concentrations in August in watersheds 819, 708, and 844 (Fig. S4), two of which (708 and 844) are known to have coho salmon (Oncorhynchus kisutch; MacAdams, 2018). However, the increase in $\mathrm{NH}_{4}^{+}$was not reflected in other constituents that would be associated with salmon (e.g., $\mathrm{NO}_{3}^{-}, \mathrm{PO}_{4}^{3-}$, DOC as in Hood et al., 2007), rather suggesting enhanced remineralisation of organic matter in soils during the summer. In nearshore waters, Wilson and Blossom River $\mathrm{PO}_{4}^{3-}$ mixed conservatively and there was little loss of $\mathrm{Fe}$ in surficial coastal waters, but the number of marine measurements taken were limited relative to the river surveys (Sugai and Burrell, 1984). dFe yields from the Calvert and Hecate watersheds were comparable to these more northerly sites (Sugai and Burrell, 1984), which also exceeded the global riverine average by 2 to 3 orders of magnitude (Table S10). DON and DIN yields from the Calvert and Hecate watersheds were very similar to those in the Peterson Creek watershed (Fellman et al., 2021), suggesting that high DON but low DIN yields from coastal forested watersheds may be a consistent feature across large swaths of the NPCTR.

Surface waters of Hecate Strait, just north of Queen Charlotte Sound along the British Columbia coast, were similar to the Redfield ratio in both summer and winter with respect to $\mathrm{N}: \mathrm{P}$ and $\mathrm{Si}: \mathrm{N}$ and exceeded the Redfield-Brzezinski Si : P ratio (Whitney et al., 2005). The Si : P ratios (21-26:1) were similar to those in the Kwakshua Channel system, but the Hecate Strait summer N : P $(13: 1)$ was much higher than the $\sim 1: 1$ in Kwakshua waters (Whitney et al., 2005), again highlighting significant spatial variability within a small area of the NPCTR. Although nutrient limitation assays in coastal waters of British Columbia are sparse, the Gulf of Alaska, which borders the northern reaches of the NPCTR, is known to be Fe-limited (Martin et al., 1989), while N co-limitation has been observed across the continental shelf (Strom et al., 2006). This spatial variability in nutrient limitation status is largely a result of the freshwater input dynamics, vertical mixing events, and horizontal transport processes, e.g., 
onshore transport of offshore waters during downwelling (Strom et al., 2006). Eddies generated on the continental shelf in the northeast Pacific can readily transport iron and other nutrients (e.g., DON) into offshore waters (Johnson et al., 2005; Ladd et al., 2009; Cullen et al., 2009). The existence of both $\mathrm{dFe}$ supply and an efficient transport mechanism suggests that the NPCTR may be a hotspot of terrestrial Fe export to offshore waters of the northeast Pacific Ocean.

The sheer diversity of both coastal ecosystems and watershed types across the NPCTR makes it difficult to apply findings uniformly from one part of the coast to the wider region. Extensive marine surveys along the Chilean coastal temperate rainforests have demonstrated highly variable nearshore nutrient profiles with differing freshwater inputs (Cuevas et al., 2019). Areas receiving greater freshwater inputs were associated with lower total chlorophyll $a$ concentrations, and phytoplankton communities dominated by small cells less than $20 \mu \mathrm{m}$ (Cuevas et al., 2019). Given that seasonality plays such an important role across coastal temperate rainforest (CTR) regions, it is imperative that more surveys be conducted year-round in recognition that freshwater and marine influences may alter the quality of nearshore waters differently throughout the year.

An additional consideration that could not be explicitly addressed here is the connection between surface and subsurface waters in relation to nutrient dynamics. Particulate organic carbon exports from the study streams are typically quite low, with concentrations consistently 1 to 2 orders of magnitude lower than the DOC exports (St. Pierre et al., 2020a). However, particulate organic matter may represent a regular subsidy to benthic communities. The subsurface waters themselves are also an important source of nutrients to the surface waters. This is of particular importance during the fall and winter when storm activity causes deep water column mixing, replenishing surface waters with $\mathrm{NO}_{3}^{-}, \mathrm{PO}_{4}^{3-}$, and $\mathrm{Si}(\mathrm{OH})_{4}$ regenerated at depth and/or advected into the area during spring/summer deep water renewal.

\subsection{Influence of high land-ocean connectivity in autumn-winter on the spring bloom}

Given that freshwater exports to nearshore ecosystems are highest in autumn and winter, we might expect exports at this time of year to play an important role in priming nearshore waters for the spring bloom. Although this wetter season coincides with lower primary production in receiving marine ecosystems, wintertime downwelling winds can be favourable for the retention of freshwater plumes in nearshore environments (Thomson, 1981). In some eastern boundary current upwelling regions, upwelling of terrestrial Fe deposited in coastal sediments may be an important source of $\mathrm{Fe}$ for nearshore waters during the summer months (Johnson et al., 1999; Chase et al., 2005). Along the Oregon coast, for example, wintertime riverine inputs stay close to shore, and freshwater inputs of limiting Fe are sufficient to support significant primary production in winter and the entirety of the spring-summer phytoplankton bloom (Wetz et al., 2006). With the switch to upwelling-favourable winds in the spring, some of this pool can then disperse and potentially support primary production over a much wider area and into offshore waters (Herzog et al., 2020b). The large freshwater $\mathrm{dFe}$ exports that we observe may therefore represent an important subsidy to both nearshore surface waters and waters offshore.

Also of potential importance are the freshwater exports of DON (304-381 $\mathrm{kg} \mathrm{km}^{-2} \mathrm{yr}^{-1}$ ), which were at the high end of the estimated range for rivers globally (10$479 \mathrm{~kg} \mathrm{~km}^{-2} \mathrm{yr}^{-1}$; Alvarez-Cobelas et al., 2008) and are seemingly a consistent feature of forested watersheds across the NPCTR (Fellman et al., 2021). Although DON has traditionally been considered resistant to microbial degradation in surface waters (Voss and Hietanen, 2013), the advective flux from coastal waters can be a potentially important source of $\mathrm{N}$ to the open ocean. Globally, waters of the eastern Pacific have high DON concentrations (Letscher et al., 2013), which may, at least in part, be influenced by high freshwater inputs that drive a clear nearshore (high) to offshore (low) gradient in DON concentrations in the region (Wong et al., 2002). However, the fate of the terrestrial DON in these waters requires further investigation (Fig. 8).

The freshwater plumes that we sampled during late summer were likely quickly dissipated by tide and wind activity. However, because of the sheer volume of fresh water exported during the autumn and winter months, combined with downwelling-favourable winds, we might expect freshwater plumes to persist for longer during these seasons. The Kwakshua Channel system is approximately $800 \mathrm{~km}$ north of the Oregon study area where Wetz et al. (2006) found high winter primary production. The Kwakshua Channel system thus has colder waters and, critically, receives less incident light during the winter than further south. Wintertime primary production is therefore likely reduced to the Oregon shelf, but the observation of such high winter primary production in nearby regions highlights the potential biogeochemical importance of what is traditionally an under-sampled season across both freshwater and marine environments. Although we cannot definitively say to what extent autumn and winter freshwater inputs may contribute to the spring bloom, such high fluxes of potentially limiting nutrients (DON, dFe) could play an important role during this understudied season.

\section{Conclusions and next steps}

Using a more-than-4-year dataset, we show that freshwater exports from small hypermaritime rainforest watersheds along the British Columbia outer coast to nearshore surface waters may directly dilute pools of inorganic nutrients in nearshore surface waters but enhance pools of organic-matter-associated nutrients that require reminerali- 
sation or chelation $(\mathrm{dFe})$ before being readily available to primary producers in surface waters. These freshwater exports have potentially important consequences for the function of nearshore waters, altering food web structure and energy transfer (Fig. 8). In particular, freshwater yields of $\mathrm{DON}$ and $\mathrm{dFe}$ across the watersheds were at the high end of $(\mathrm{DON})$ or greatly exceeded $(\mathrm{dFe})$ currently documented global ranges of riverine nutrient yields to coastal waters.

Based on these results, a number of future research priorities have emerged. Of primary importance will be to understand which nutrients are limiting in coastal waters of the NPCTR throughout the year (Fig. 8). Of secondary importance will be to resolve (a) the nature of the freshwater $\mathrm{dFe}$ exports (organic vs. inorganic complexes, identity of ligands), which ultimately determines the lability and downstream fate of this potentially critical nutrient (Herzog et al., 2020b); and (b) the fate of the freshwater DON exports within the nearshore waters (i.e., extent of microbial remineralisation, photoammonification, uptake) (Fig. 8). In contrast to the field's prevailing focus on inorganic macronutrients $\left(\mathrm{NO}_{3}^{-}, \mathrm{PO}_{4}^{3-}, \mathrm{Si}(\mathrm{OH})_{4}\right)$, our results highlight the need to measure organic nutrient (DON, DOP) concentrations to fully understand the impact of freshwater exports on nearshore ecosystems.

Coastal waters of the northeast Pacific Ocean receive nutrients from multiple terrestrial freshwater sources, including rainfall, snow, and glacial melt (Hood and Berner, 2009; Edwards et al., 2013), as well as from multiple marine sources, including upwelling and exchange with offshore waters (Thomson, 1981). To date, much of the work examining the impacts of this watershed diversity on nearshore ecosystems has focused on differences in the lability of dissolved organic matter from these various hydrological sources to marine ecosystems (e.g., Arimitsu et al., 2018; Hood and Berner, 2009; Hood et al., 2009; Fellman et al., 2010). Variability in nutrient $(\mathrm{N}, \mathrm{P}, \mathrm{Si}, \mathrm{Fe})$ sources across the wider NPCTR region, however, remains largely unexplored. A concerted effort across the region is thus needed to better understand how this diversity of nutrient sources impacts nutrient availability and subsequent autotrophic and heterotrophic production in coastal waters (Bidlack et al., 2021).

Data availability. Weather records and nutrient and carbon chemistry data and fluxes are available in St. Pierre et al. (2020b). Discharge data are available in Korver et al. (2019a) (https://doi.org/10.21966/zvwf-qn04). Weather station data were compared against the downscaled climate normal for each station, extracted using station coordinates (Table S3) in the openaccess web service (http://www.climatewna.com/ (last access: 25 May 2020), from Wang et al., 2016).

Supplement. The supplement related to this article is available online at: https://doi.org/10.5194/bg-18-3029-2021-supplement.
Author contributions. KASP conducted the data analyses and wrote the manuscript. BPVH, SET, IG, AAO, and KPL designed the study. IG coordinated the routine freshwater sampling campaigns and data management. MCK coordinated the storm event samplings and data management, with oversight from WF. WF and MCK collected, processed, and managed the discharge and weather data across the study watersheds. SET, BPVH, IG, MCK, and AAO designed the freshwater plume surveys, which were implemented by MCK and AAO. All authors contributed to the drafting of the manuscript.

Competing interests. The authors declare that they have no conflict of interest.

Acknowledgements. We gratefully acknowledge that this work was conducted on the traditional, ancestral, and unceded territories of the Heiltsuk and Wuikinuxv First Nations. We would like to sincerely thank the Hakai Institute for designing and operating the Kwakshua Watersheds Observatory, with special thanks to Jennifer Jackson for coordinating sampling campaigns and data management for the oceanography team. Field work was conducted by Bryn Fedje, Lucy Quayle, Emma Myers, Christopher Coxson, Isabelle Desmarais, Emily Haughton, Chris Mackenzie, Skye McEwan, Chris O'Sullivan, and Rob White. Glen Woodsworth kindly provided the raw data associated with the Roddick (1996) report from the Geological Survey of Canada. Keith Holmes produced Fig. 1, and Frances Biles provided the shapefile delineation of the NPCTR regions used in Fig. 1. We also thank Paul Sanborn for useful discussion on the role of bedrock geomorphology and pedology in affecting freshwater nutrient exports, as well as Mark Garrison for producing Fig. 8. Salary support to SET was provided by the Campus Alberta Innovates Program.

Financial support. This research has been supported by the Tula Foundation (grant no. N/A).

Review statement. This paper was edited by Koji Suzuki and reviewed by two anonymous referees.

\section{References}

Alaback, P. B.: Biodiversity Patterns in Relation to Climate: The Coastal Temperate Rainforests of North America, in: HighLatitude Rainforests and Associated Ecosystems of the West Coast of the Americas: Climate, Hydrology, Ecology, and Conservation, edited by: Lawford, R. G., Fuentes, E., and Alaback, P. B., Springer New York, New York, USA, 105-133, 1996.

Alvarez-Cobelas, M., Angeler, D. G., and SánchezCarrillo, S.: Export of nitrogen from catchments: A worldwide analysis, Environ. Pollut., 156, 261-269, https://doi.org/10.1016/j.envpol.2008.02.016, 2008.

Analytical Methods Committee: What should be done with results below the detection limit? Mentioning the un- 
mentionable, AMC Technical Brief, Royal Society of Chemistry, available at: https://www.rsc.org/images/ results-below-detection-limit-technical-brief-5_tcm18-214854. pdf (last access: 17 January 2021), London, UK, 2001.

Arimitsu, M. L., Hobson, K. A., Webber, D. A. N., Piatt, J. F., Hood, E. W., and Fellman, J. B.: Tracing biogeochemical subsidies from glacier runoff into Alaska's coastal marine food webs, Global Change Biol., 24, 387-398, https://doi.org/10.1111/gcb.13875, 2018.

Batchelli, S., Muller, F. L. L., Chang, K.-C., and Lee, C.-L.: Evidence for Strong but Dynamic Iron-Humic Colloidal Associations in Humic-Rich Coastal Waters, Environ. Sci. Technol., 44, 8485-8490, https://doi.org/10.1021/es101081c, 2010.

Bates, D., Maechler, M., Bolker, B., and Walker, S.: Fitting Linear Mixed-Effects Models Using lme4, J. Stat. Softw., 67, 1-48, https://doi.org/10.18637/jss.v067.i01, 2015.

Bauer, J. E., Cai, W.-J., Raymond, P. A., Bianchi, T. S., Hopkinson, C. S., and Regnier, P. A. G.: The changing carbon cycle of the coastal ocean, Nature, 504, 61-70, https://doi.org/10.1038/nature12857, 2013.

Benitez-Nelson, C. R.: The biogeochemical cycling of phosphorus in marine systems, Earth-Sci. Rev., 51, 109-135, https://doi.org/10.1016/S0012-8252(00)00018-0, 2000.

Bidlack, A. L., Bisbing, S. M., Buma, B. J., Diefenderfer, H. L., Fellman, J. B., Floyd, W. C., Giesbrecht, I., Lally, A., Lertzman, K. P., Perakis, S. S., Butman, D. E., D’Amore, D. V., Fleming, S. W., Hood, E. W., Hunt, B. P. V., Kiffney, P. M., McNicol, G., Menounos, B., and Tank, S. E.: Climate-Mediated Changes to Linked Terrestrial and Marine Ecosystems across the Northeast Pacific Coastal Temperate Rainforest Margin, BioScience, biaa171, https://doi.org/10.1093/biosci/biaa171, 2021.

Boiteau, R. M., Till, C. P., Coale, T. H., Fitzsimmons, J. N., Bruland, K. W., and Repeta, D. J.: Patterns of iron and siderophore distributions across the California Current System, Limnol. Oceanogr., 64, 376-389, https://doi.org/10.1002/lno.11046, 2019.

Bouwman, A. F., Bierkens, M. F. P., Griffioen, J., Hefting, M. M., Middelburg, J. J., Middelkoop, H., and Slomp, C. P.: Nutrient dynamics, transfer and retention along the aquatic continuum from land to ocean: towards integration of ecological and biogeochemical models, Biogeosciences, 10, 1-22, https://doi.org/10.5194/bg-10-1-2013, 2013.

Boyer, E. W., Hornberger, G. M., Bencala, K. E., and McKnight, D. M.: Response characteristics of DOC flushing in an alpine catchment, Hydrol. Process., 11, 1635-1647, https://doi.org/10.1002/(SICI)10991085(19971015)11:12<1635::AID-HYP494>3.0.CO;2-H, 1997.

Brigode, P., Mićović, Z., Bernardara, P., Paquet, E., Garavaglia, F., Gailhard, J., and Ribstein, P.: Linking ENSO and heavy rainfall events over coastal British Columbia through a weather pattern classification, Hydrol. Earth Syst. Sci., 17, 1455-1473, https://doi.org/10.5194/hess-17-1455-2013, 2013.

Bruland, K. W., Rue, E. L., and Smith, G. J.: Iron and macronutrients in California coastal upwelling regimes: Implications for diatom blooms, Limnol. Oceanogr., 46, 1661-1674, https://doi.org/10.4319/lo.2001.46.7.1661, 2001.

Brzezinski, M. A.: The $\mathrm{Si}: \mathrm{C}: \mathrm{N}$ ratio of marine diatoms: Interspecific variability and the effect of some environmental vari- ables, J. Phycol., 21, 347-357, https://doi.org/10.1111/j.00223646.1985.00347.x, 1985.

Chase, Z., Hales, B., Cowles, T., Schwartz, R., and van Geen, A.: Distribution and variability of iron input to Oregon coastal waters during the upwelling season, J. Geophys. Res.-Oceans, 110, C10S12, https://doi.org/10.1029/2004JC002590, 2005.

Climate Prediction Center: Cold \& Warm Episodes by Season, Climate Prediction Center, NOAA/National Weather Service, Online, 2019.

Cuevas, L. A., Tapia, F. J., Iriarte, J. L., González, H. E., Silva, N., and Vargas, C. A.: Interplay between freshwater discharge and oceanic waters modulates phytoplankton size-structure in fjords and channel systems of the Chilean Patagonia, Prog. Oceanogr., 173, 103-113, https://doi.org/10.1016/j.pocean.2019.02.012, 2019.

Cullen, J. T., Chong, M., and Ianson, D.: British Columbian continental shelf as a source of dissolved iron to the subarctic northeast Pacific Ocean, Global Biogeochem. Cy., 23, GB4012, https://doi.org/10.1029/2008GB003326, 2009.

De Baar, H. J. W. and De Jong, J. T. M.: Distributions, sources and sinks of iron in seawater, in: The Biogeochemistry of Iron in Seawater, edited by: Turner, D. R. and Hunter, K. A., IUPAC Series on Analytical and Physical Chemistry of Environmental Systems, J. Wiley, Chichester; Rexdale, Ont., 123-253, 2001.

DellaSala, D. A.: Temperate and Boreal Rainforests of the World: Ecology and Conservation, Island Press/Center for Resource Economics, Washington D.C., USA, 2011.

Diaz, F. and Raimbault, P.: Nitrogen regeneration and dissolved organic nitrogen release during spring in a NW Mediterranean coastal zone (Gulf of Lions): implications for the estimation of new production, Mar. Ecol. Prog. Ser., 197, 51-65, https://doi.org/10.3354/meps 197051, 2000.

Dürr, H. H., Meybeck, M., Hartmann, J., Laruelle, G. G., and Roubeix, V.: Global spatial distribution of natural riverine silica inputs to the coastal zone, Biogeosciences, 8, 597-620, https://doi.org/10.5194/bg-8-597-2011, 2011.

Eamer, J. and Shugar, D. H.: Geomorphology - Calvert Island, Hakai Institute, Victoria, British Columbia, Canada, 2015.

Ecotrust, Pacific GIS, and Conservation International: Original distribution of the Coastal Temperate Rain Forest, in: The Rainforests of Home: An Atlas of People and Place, Interrain, Portland, Oregon, USA, 1995.

Edwards, R. T., D'Amore, D. V., Norberg, E., and Biles, F.: Riparian Ecology, Climate Change, and Management in North Pacific Coastal Rainforests, in: North Pacific Temperate Rainforests: Ecology and Conservation, edited by: Orians, G. H., and Schoen, J. W., Audubon Alaska, Anchorage, Alaska, USA, 43-72, 2013.

Edwards, T. K. and Glysson, G. D.: Field methods for measurement of fluvial sediment, in: Techniques of Water-Resources Investigations of the U.S. Geological Survey, Applications of Hydraulics, U.S. Geological Survey, Reston, Virginia, USA, 1999.

Eppley, R. W. and Peterson, B. J.: Particulate organic matter flux and planktonic new production in the deep ocean, Nature, 282, 677-680, https://doi.org/10.1038/282677a0, 1979.

Fellman, J. B., Hood, E., D'Amore, D. V., Edwards, R. T., and White, D.: Seasonal changes in the chemical quality and biodegradability of dissolved organic matter exported from soils to streams in coastal temperate rainforest watersheds, Bio- 
geochemistry, 95, 277-293, https://doi.org/10.1007/s10533-0099336-6, 2009a.

Fellman, J. B., Hood, E., Edwards, R. T., and D'Amore, D. V.: Changes in the concentration, biodegradability, and fluorescent properties of dissolved organic matter during stormflows in coastal temperate watersheds, J. Geophys. Res.-Biogeo., 114, G01021, https://doi.org/10.1029/2008JG000790, 2009 b.

Fellman, J. B., Hood, E., Edwards, R. T., and Jones, J. B.: Uptake of Allochthonous Dissolved Organic Matter from Soil and Salmon in Coastal Temperate Rainforest Streams, Ecosystems, 12, 747759, https://doi.org/10.1007/s10021-009-9254-4, 2009c.

Fellman, J. B., Spencer, R. G. M., Hernes, P. J., Edwards, R. T., D'Amore, D. V., and Hood, E.: The impact of glacier runoff on the biodegradability and biochemical composition of terrigenous dissolved organic matter in near-shore marine ecosystems, Mar. Chem., 121, 112-122, https://doi.org/10.1016/j.marchem.2010.03.009, 2010.

Fellman, J. B., Hood, E., D'Amore, D. V., and Edwards, R. T.: Streamflow variability controls $\mathrm{N}$ and $\mathrm{P}$ export and speciation from Alaskan coastal temperate rainforest watersheds, Biogeochemistry, 152, 253-270, https://doi.org/10.1007/s10533-02000752-w, 2021. Volume: 152 Page numbers:

Fleming, S. W., Hood, E., Dahlke, H. E., and O'Neel, S.: Seasonal flows of international British Columbia-Alaska rivers: The nonlinear influence of ocean-atmosphere circulation patterns, Adv. Water Resour., 87, 42-55, https://doi.org/10.1016/j.advwatres.2015.10.007, 2016.

Giesbrecht, I., Floyd, W. C., Korver, M. C., Hunt, B. P. V., Lertzman, K. P., Oliver, A. A., and Tank, S. E.: Monitoring pluvial watershed dynamics on the Central Coast (Calvert Island): Sensor and sampling data from 2013 to 2015, in: State of the Physical, Biological and Selected Fishery Resources of Pacific Canadian Marine Ecosystems in 2015 ,edited by: Chandler, P. C., King, S. A., and Perry, R. I., Hakai Institute, Dept. Fisheries and Oceans Canada, Sidney, British Columbia, Canada, Can. Tech. Rep. Fish. Aquat. Sci. No. 3179, 214-217, available at: http://waves-vagues.dfo-mpo.gc.ca/Library/365564.pdf (last access: 25 May 2020), 2016.

Giesbrecht, I., Floyd, W. C., Tank, S. E., Lertzman, K. P., Hunt, B. P. V., Korver, M. C., Oliver, A. A., Brunsting, R., Sanborn, P., Gonzalez Arriola, S. G., Frazer, G. F., Hateley, S., McPhail, J., Owen, C., Butler, S., Fedje, B., Myers, E., Quayle, L., Haughton, E., Desmarais, I., White, R., Levy-Booth, D. J., Kellogg, C. T. E., Jackson, J. M., St. Pierre, K. A., Mohn, W. W., Hallam, S. J., and Del Bel Belluz, J.: The Kwakshua Watersheds Observatory, Central Coast of British Columbia, Canada, submitted to Hydrol. Process., in press., 2021.

Goldman, J. C., Caron, D. A., and Dennett, M. R.: Regulation of gross growth efficiency and ammonium regeneration in bacteria by substrate $\mathrm{C}: \mathrm{N}$ ratio, Limnol. Oceanogr., 32, 1239-1252, https://doi.org/10.4319/lo.1987.32.6.1239, 1987.

Goñi, M. A., Hatten, J. A., Wheatcroft, R. A., and Borgeld, J. C.: Particulate organic matter export by two contrasting small mountainous rivers from the Pacific Northwest, USA, J. Geophys. Res.-Biogeo., 118, 112-134, https://doi.org/10.1002/jgrg.20024, 2013.

Gonzalez Arriola, S., Frazer, G. W., and Giesbrecht, I. J. W.: LiDAR-derived watersheds and their metrics for
Calvert Island, Hakai Institute Data Package, available at: https://doi.org/10.21966/1.15311, 2015.

Harding, J. M. S. and Reynolds, J. D.: From earth and ocean: investigating the importance of cross-ecosystem resource linkages to a mobile estuarine consumer, Ecosphere, 5, 54, https://doi.org/10.1890/ES14-00029.1, 2014.

Hartmann, J. and Moosdorf, N.: Global Lithological Map Database v1.0 (gridded to $0.5 \infty$ spatial resolution), in: Supplement to: Hartmann, J. and Moosdorf, N. (2012): The new global lithological map database GLiM: A representation of rock properties at the Earth surface, Geochem. Geophy. Geosy., 13, Q12004, https://doi.org/10.1029/2012GC004370, PANGAEA, 2012.

Hedges, J. I., Keil, R. G., and Benner, R.: What happens to terrestrial organic matter in the ocean?, Org. Geochem., 27, 195-212, https://doi.org/10.1016/S0146-6380(97)00066-1, 1997.

Helsel, D. R.: Summing Nondetects: Incorporating Low-Level Contaminants in Risk Assessment, Integr. Environ. Asses., 6, 361366, https://doi.org/10.1002/IEAM.31, 2009.

Herzog, S. D., Gentile, L., Olsson, U., Persson, P., and Kritzberg, E. S.: Characterization of iron and organic carbon colloids in boreal rivers and their fate at high salinity, J. Geophys. Res.-Biogeo., 125, e2019JG005517, https://doi.org/10.1029/2019JG005517, 2020a.

Herzog, S. D., Persson, P., Kvashnina, K., and Kritzberg, E. S.: Organic iron complexes enhance iron transport capacity along estuarine salinity gradients of Baltic estuaries, Biogeosciences, 17, 331-344, https://doi.org/10.5194/bg-17-331-2020, 2020 b.

Hitchcock, J. N., Mitrovic, S. M., Hadwen, W. L., Roelke, D. L., Growns, I. O., and Rohlfs, A.-M.: Terrestrial dissolved organic carbon subsidizes estuarine zooplankton: An in situ mesocosm study, Limnol. Oceanogr., 61, 254-267, https://doi.org/10.1002/lno.10207, 2016.

Ho, T.-Y., Quigg, A., Finkel, Z. V., Milligan, A. J., Wyman, K., Falkowski, P. G., and Morel, F. M. M.: The elemental composition of some marine phytoplankton, J. Phycol., 39, 1145-1159, https://doi.org/10.1111/j.0022-3646.2003.03-090.x, 2003.

Hoffman, J. C., Bronk, D. A., and Olney, J. E.: Organic Matter Sources Supporting Lower Food Web Production in the Tidal Freshwater Portion of the York River Estuary, Virginia, Estuar. Coast., 31, 898-911, https://doi.org/10.1007/s12237-008-90734, 2008.

Hood, E. and Berner, L.: Effects of changing glacial coverage on the physical and biogeochemical properties of coastal streams in southeastern Alaska, J. Geophys. Res.-Biogeo., 114, G03001, https://doi.org/10.1029/2009JG000971, 2009.

Hood, E., Gooseff, M. N., and Johnson, S. L.: Changes in the character of stream water dissolved organic carbon during flushing in three small watersheds, Oregon, J. Geophys. Res.-Biogeo., 111, G01007, https://doi.org/10.1029/2005JG000082, 2006.

Hood, E., Fellman, J., and Edwards, R. T.: Salmon influences on dissolved organic matter in a coastal temperate brownwater stream: An application of fluorescence spectroscopy, Limnol. Oceanogr., 52, 1580-1587, https://doi.org/10.4319/lo.2007.52.4.1580, 2007.

Hood, E., Fellman, J., Spencer, R. G. M., Hernes, P. J., Edwards, R., D'Amore, D., and Scott, D.: Glaciers as a source of ancient and labile organic matter to the marine environment, Nature, 462, 1044-1047, https://doi.org/10.1038/nature08580, 2009. 
Hunt, B. P. V., Jackson, J. M., Del Bel Belluz, J., and Barrette, J.: Hakai Oceanography Program: British Columbia Central Coast Time Series (2012-2017), in: State of the Physical, Biological and Selected Fishery Resources of Pacific Canadian Marine Ecosystems in 2017, edited by: Chandler, P. C., King, S. A., and Boldt, J., Government report available at: https://dfo-mpo.gc.ca/ oceans/publications/soto-rceo/2017/index-eng.html (last access: 25 May 2020), Nanaimo, BC, Canada by Department of Fisheries and Oceans Canada, 33-37, 2018.

Isles, P. D. F.: The misuse of ratios in ecological stoichiometry, Ecology, 101, e03153, https://doi.org/10.1002/ecy.3153, 2020.

Johnson, K. S., Chavez, F. P., and Friederich, G. E.: Continentalshelf sediment as a primary source of iron for coastal phytoplankton, Nature, 398, 697-700, https://doi.org/10.1038/19511, 1999.

Johnson, W. K., Miller, L. A., Sutherland, N. E., and Wong, C. S.: Iron transport by mesoscale Haida eddies in the Gulf of Alaska, Deep-Sea Res. Pt. II, 52, 933-953, https://doi.org/10.1016/j.dsr2.2004.08.017, 2005.

Jones, D. L.: Organic acids in the rhizosphere - a critical review, Plant Soil, 205, 25-44, https://doi.org/10.1023/A:1004356007312, 1998.

Keller, C. K.: Carbon exports from terrestrial ecosystems: A critical-zone framework, Ecosystems, 22, 1691-1705, https://doi.org/10.1007/s10021-019-00375-9, 2019.

Kiffney, P. M., Bull, J. P., and Feller, M. C.: Climatic and hydrologic variability in a coastal watershed of southwestern British Columbia, J. Am. Water Resour. As., 38, 1437-1451, https://doi.org/10.1111/j.1752-1688.2002.tb04357.x, 2002.

Klawonn, I., Bonaglia, S., Whitehouse, M. J., Littmann, S., Tienken, D., Kuypers, M. M. M., Brüchert, V., and Ploug, H.: Untangling hidden nutrient dynamics: rapid ammonium cycling and single-cell ammonium assimilation in marine plankton communities, ISME J., 13, 1960-1974, https://doi.org/10.1038/s41396019-0386-z, 2019.

Körtzinger, A., Koeve, W., Kähler, P., and Mintrop, L.: C : N ratios in the mixed layer during the productive season in the northeast Atlantic Ocean, Deep-Sea Res. Pt. I, 48, 661-688, https://doi.org/10.1016/S0967-0637(00)00051-0, 2001.

Korver, M. C., Floyd, W. C., and Brunsting, R.: Observed streamflow from seven small coastal watersheds in British Columbia, Canada, September 2013-April 2019, Version 4.1, Hakai Institute Dataset, available at: https://doi.org/10.21966/zvwf-qn04, 2019a.

Korver, M. C., Giesbrecht, I., Floyd, W. C., Oliver, A. A., and Tank, S. E.: Stream event biogeochemistry of seven small watersheds at Calvert Island, British Columbia, Canada, July 2015November 2018, Version 2, Hakai Institute Dataset, available at: https://doi.org/10.21966/3nm8-av33, 2019b.

Krachler, R., Jirsa, F., and Ayromlou, S.: Factors influencing the dissolved iron input by river water to the open ocean, Biogeosciences, 2, 311-315, https://doi.org/10.5194/bg-2-3112005, 2005.

Ladd, C., Crawford, W. R., Harpold, C. E., Johnson, W. K., Kachel, N. B., Stabeno, P. J., and Whitney, F.: A synoptic survey of young mesoscale eddies in the Eastern Gulf of Alaska, Deep-Sea Res. Pt. II, 56, 2460-2473, https://doi.org/10.1016/j.dsr2.2009.02.007, 2009.
Lauderdale, J. M., Braakman, R., Forget, G., Dutkiewicz, S., and Follows, M. J.: Microbial feedbacks optimize ocean iron availability, P. Natl. Acad. Sci. USA, 117, 4842-4849, https://doi.org/10.1073/pnas.1917277117, 2020.

Lenth, R. V.: Least-Square Means: The R Package 1smeans, J. Stat. Softw., 69, 1-33, https://doi.org/10.18637/jss.v069.i01, 2016.

Letscher, R. T., Hansell, D. A., Carlson, C. A., Lumpkin, R., and Knapp, A. N.: Dissolved organic nitrogen in the global surface ocean: Distribution and fate, Global Biogeochem. Cy., 27, 141153, https://doi.org/10.1029/2012GB004449, 2013.

Ling Ong, H., Swanson, V. E., and Bisque, R. E.: Natural organic acids as agents of chemical weathering, United States Department of the Interior, United States Geological Survey, Mounds View, Minnesota, USA, 130-137, 1970.

Lorenz, D., Runkel, R., and De Cicco, L.: rloadest: river load estimation, US Geological Survey, Mounds View, Minnesota, USA, 2015.

MacAdams, J.: Fish forensics: environmental DNA detection of juvenile coho salmon and resident salmonids in Pacific coastal streams, School of Environmental Studies, University of Victoria, Victoria, British Columbia, Canada, 79 pp., 2018.

Martin, J. H., Gordon, R. M., Fitzwater, S., and Broenkow, W. W.: Vertex: phytoplankton/iron studies in the Gulf of Alaska, Deep-Sea Res., 36, 649-680, https://doi.org/10.1016/01980149(89)90144-1, 1989.

Martiny, A. C., Pham, C. T. A., Primeau, F. W., Vrugt, J. A., Moore, J. K., Levin, S. A., and Lomas, M. W.: Strong latitudinal patterns in the elemental ratios of marine plankton and organic matter, Nat. Geosci., 6, 279-283, https://doi.org/10.1038/ngeo1757, 2013.

Matsunaga, K., Nishioka, J., Kuma, K., Toya, K., and Suzuki, Y.: Riverine input of bioavailable iron supporting phytoplankton growth in Kesennuma Bay (Japan), Water Res., 32, 3436-3442, https://doi.org/10.1016/S0043-1354(98)00113-4, 1998.

McNicol, G., Bulmer, C., D’Amore, D., Sanborn, P., Saunders, S., Giesbrecht, I., Arriola, S. G., Bidlack, A., Butman, D., and Buma, B.: Large, climate-sensitive soil carbon stocks mapped with pedology-informed machine learning in the North Pacific coastal temperate rainforest, Environ. Res. Lett., 14, 014004, https://doi.org/10.1088/1748-9326/aaed52, 2019.

Meidinger, D. and Pojar, J.: Ecosystems of British Columbia, B. C. Ministry of Forests Series: Special Report Series 6, Victoria, BC, Canada, 330 pp., 1991.

Meybeck, M.: Carbon, nitrogen, and phosphorus transport by world rivers, Am. J. Sci., 282, 401-450, 1982.

Moore, C. M., Mills, M. M., Arrigo, K. R., Berman-Frank, I., Bopp, L., Boyd, P. W., Galbraith, E. D., Geider, R. J., Guieu, C., Jaccard, S. L., Jickells, T. D., La Roche, J., Lenton, T. M., Mahowald, N. M., Marañón, E., Marinov, I., Moore, J. K., Nakatsuka, T., Oschlies, A., Saito, M. A., Thingstad, T. F., Tsuda, A., and Ulloa, O.: Processes and patterns of oceanic nutrient limitation, Nat. Geosci., 6, 701-710, https://doi.org/10.1038/ngeo1765, 2013.

Morrison, J., Foreman, M. G. G., and Masson, D.: A method for estimating monthly freshwater discharge affecting British Columbia coastal waters, Atmos. Ocean, 50, 1-8, https://doi.org/10.1080/07055900.2011.637667, 2012. 
Nash, J. E. and Sutcliffe, J. V.: River flow forecasting through conceptual models part I - A discussion of principles, J. Hydrol., 10, 282-290, https://doi.org/10.1016/0022-1694(70)90255-6, 1970.

Neal, E. G., Hood, E., and Smikrud, K.: Contribution of glacier runoff to freshwater discharge into the Gulf of Alaska, Geophys. Res. Lett., 37, L06404, https://doi.org/10.1029/2010GL042385, 2010.

O’Neel, S., Hood, E., Bidlack, A. L., Fleming, S. W., Arimitsu, M. L., Arendt, A., Burgess, E., Sergeant, C. J., Beaudreau, A. H., Timm, K., Hayward, G. D., Reynolds, J. H., and Pyare, S.: Icefield-to-ocean linkages across the Northern Pacific coastal temperate rainforest ecosystem, BioScience, 65, 499512, https://doi.org/10.1093/biosci/biv027, 2015.

Oksanen, J., Blanchet, F. G., Friendly, M., Kindt, R., Legendre, P., McGlinn, D., Minchin, P. R., O’Hara, R. B., Simpson, G. L., Solymos, P., Stevens, M. H. H., Szoecs, E., and Wagner, H.: Package "vegan", 2018.

Oliver, A. A., Tank, S. E., Giesbrecht, I., Korver, M. C., Floyd, W. C., Sanborn, P., Bulmer, C., and Lertzman, K. P.: A global hotspot for dissolved organic carbon in hypermaritime watersheds of coastal British Columbia, Biogeosciences, 14, 37433762, https://doi.org/10.5194/bg-14-3743-2017, 2017.

Perez, B. C., Day, J. W., Justic, D., Lane, R. R., and Twilley, R. R.: Nutrient stoichiometry, freshwater residence time, and nutrient retention in a river-dominated estuary in the Mississippi Delta, Hydrobiologia, 658, 41-54, https://doi.org/10.1007/s10750-0100472-8, 2011.

Redfield, A. C.: On the proportions of organic derivatives in sea water and their relation to the composition of plankton, in: James Johnstone Memorial Volume Lancashire Sea-Fisheries Laboratory, Liverpool Univ. Press, Liverpool, UK, 176-192, 1934.

Roddick, J. A.: Geology Rivers Inlet (92M) - Queens Sound (102P) Map Areas, Geological Survey of Canada, Ottawa, ON, Canada, 39 pp., 1996.

Royer, T. C.: Coastal fresh water discharge in the northeast Pacific, J. Geophys. Res.-Oceans, 87, 2017-2021, https://doi.org/10.1029/JC087iC03p02017, 1982.

Runkel, R.: Revisions to LOADEST, April 2013, USGS, https:// water.usgs.gov/software/loadest/doc/loadest_update.pdf (last access: 13 June 2020), 2013.

Runkel, R. L., Crawford, C. G., and Cohn, T. A.: Load estimator (LOADEST): a FORTRAN program for estimating constituent loads in streams and rivers, in: USGS Techniques and Methods Book 4, US Geological Survey, Reston, Virginia, USA, 2004.

Sakamaki, T. and Richardson, J. S.: Effects of small rivers on chemical properties of sediment and diets for primary consumers in estuarine tidal flats, Mar. Ecol. Prog. Ser., 360, 13-24, https://doi.org/10.3354/meps07388, 2008.

Salkfield, T., Walton, A., and Mackenzie, W.: Biogeoclimatic Ecosystem Classification Map, Ministry of Forests, Lands, Natural Resource Operations and Rural Development, available at: https://catalogue.data.gov.bc.ca/dataset/bec-map (last access: 7 August 2020), 2016.

Sanderman, J., Lohse, K. A., Baldock, J. A., and Amundson, R.: Linking soils and streams: Sources and chemistry of dissolved organic matter in a small coastal watershed, Water Resour. Res., 45, W03418, https://doi.org/10.1029/2008wr006977, 2009.

Shiller, V. J.: Spring and summer phytoplankton community dynamics and comparison of FRRF- and ${ }^{13} \mathrm{C}$-derived measure- ments of primary productivity in Rivers Inlet, British Columbia, M.Sc., Faculty of Graduate Studies, University of British Columbia, Vancouver, British Columbia, Canada, 103 pp., 2012.

Stenback, G. A., Crumpton, W. G., Schilling, K. E., and Helmers, M. J.: Rating curve estimation of nutrient loads in Iowa rivers, J. Hydrol., 396, 158-169, https://doi.org/10.1016/j.jhydrol.2010.11.006, 2011.

Sterner, R. W. and Elser, J. J.: Ecological stoichiometry: the biology of the elements from molecules to the biosphere, Princeton University Press, Princeton, New Jersey, USA, 439 pp., 2002.

St. Pierre, K. A., Oliver, A. A., Tank, S. E., Hunt, B. P. V., Giesbrecht, I., Kellogg, C. T. E., Jackson, J. M., Lertzman, K. P., Floyd, W. C., and Korver, M. C.: Terrestrial exports of dissolved and particulate organic carbon affect nearshore ecosystems of the Pacific coastal temperate rainforest, Limnol. Oceanogr., 65, 2657-2675, https://doi.org/10.1002/lno.11538, 2020a.

St. Pierre, K. A., Hunt, B. P. V., Tank, S. E., Giesbrecht, I., Floyd, W. C., Korver, M. C., and Lertzman, K. P.: Nutrient and dissolved organic carbon in fresh and marine waters of Kwakshua Channel, British Columbia, Canada, Version 1.0, Hakai Institute Dataset, available at: https://doi.org/10.21966/n0h9-cq15, 2020b.

Strom, S. L., Olson, M. B., Macri, E. L., and Mordy, C. W.: Cross-shelf gradients in phytoplankton community structure, nutrient utilization, and growth rate in the coastal Gulf of Alaska, Mar. Ecol. Prog. Ser., 328, 75-92, https://doi.org/10.3354/meps328075, 2006.

Sugai, S. F. and Burrell, D. C.: Transport of Dissolved Organic Carbon, Nutrients, and Trace Metals from the Wilson and Blossom Rivers to Smeaton Bay, Southeast Alaska, Can. J. Fish. Aquat. Sci., 41, 180-190, https://doi.org/10.1139/f84-019, 1984.

Takeda, S.: Influence of iron availability on nutrient consumption ratio of diatoms in oceanic waters, Nature, 393, 774-777, https://doi.org/10.1038/31674, 1998

Tank, S. E., Manizza, M., Holmes, R. M., McClelland, J. W., and Peterson, B. J.: The Processing and Impact of Dissolved Riverine Nitrogen in the Arctic Ocean, Estuar. Coast., 35, 401-415, https://doi.org/10.1007/s12237-011-9417-3, 2012.

Terhaar, J., Lauerwald, R., Regnier, P., Gruber, N., and Bopp, L.: Around one third of current Arctic Ocean primary production sustained by rivers and coastal erosion, Nat. Commun., 12, 169, https://doi.org/10.1038/s41467-020-20470-z, 2021.

Thompson, S. D., Nelson, T. A., Giesbrecht, I., Frazer, G., and Saunders, S. C.: Data-driven regionalization of forested and non-forested ecosystems in coastal British Columbia with LiDAR and RapidEye imagery, Appl. Geogr., 69, 35-50, https://doi.org/10.1016/j.apgeog.2016.02.002, 2016.

Thomson, R. E.: Northern Shelf Region, in: Oceanography of the British Columbia Coast, Canadian Special Publication of Fisheries and Aquatic Sciences, Department of Fisheries and Oceans, Ottawa, Ontario, Canada, 235-245, 1981.

Thomson, R. E., Heesemann, M., Davis, E. E., and Hourston, R. A. S.: Continental microseismic intensity delineates oceanic upwelling timing along the west coast of North America, Geophys. Res. Lett., 41, 6872-6880, https://doi.org/10.1002/2014GL061241, 2014.

Voss, M. and Hietanen, S.: The depths of nitrogen cycling, Nature, 493, 616-618, https://doi.org/10.1038/493616a, 2013. 
Walker, T. W. and Syers, J. K.: The fate of phosphorus during pedogenesis, Geoderma, 15, 1-19, https://doi.org/10.1016/00167061(76)90066-5, 1976.

Wang, H., Yang, Z., Saito, Y., Liu, J. P., and Sun, X.: Interannual and seasonal variation of the Huanghe (Yellow River) water discharge over the past 50 years: Connections to impacts from ENSO events and dams, Global Planet. Change, 50, 212-225, https://doi.org/10.1016/j.gloplacha.2006.01.005, 2006.

Wang, T., Hamann, A., Spittlehouse, D., and Carroll, C.: Locally Downscaled and Spatially Customizable Climate Data for Historical and Future Periods for North America, PLOS ONE, 11, e0156720, https://doi.org/10.1371/journal.pone.0156720, 2016.

Ward, P. J., Beets, W., Bouwer, L. M., Aerts, J. C. J. H., and Renssen, H.: Sensitivity of river discharge to ENSO, Geophys. Res. Lett., 37, L12402, https://doi.org/10.1029/2010GL043215, 2010.

Welti, N., Striebel, M., Ulseth, A. J., Cross, W. F., DeVilbiss, S., Glibert, P. M., Guo, L., Hirst, A. G., Hood, J., Kominoski, J. S., MacNeill, K. L., Mehring, A. S., Welter, J. R., and Hillebrand, H.: Bridging Food Webs, Ecosystem Metabolism, and Biogeochemistry Using Ecological Stoichiometry Theory, Front. Microbiol., 8, 1298, https://doi.org/10.3389/fmicb.2017.01298, 2017.

Wetz, M. S., Hales, B., Chase, Z., Wheeler, P. A., and Whitney, M. M.: Riverine input of macronutrients, iron, and organic matter to the coastal ocean off Oregon, USA, during the winter, Limnol. Oceanogr., 51, 2221-2231, https://doi.org/10.4319/lo.2006.51.5.2221, 2006.

Wetzel, R. G.: Limnology, edn. 3, Academic Press, San Diego, California, USA, 1006 pp., 2001.
Weyhenmeyer, G. A. and Conley, D. J.: Large differences between carbon and nutrient loss rates along the land to ocean aquatic continuum-implications for energy:nutrient ratios at downstream sites, Limnol. Oceanogr., 62, 183-193, https://doi.org/10.1002/lno.10589, 2017.

Whitney, F. A. and Welch, D. W.: Impact of the 1997-1998 El Niño and 1999 La Niña on nutrient supply in the Gulf of Alaska, Prog. Oceanogr., 54, 405-421, https://doi.org/10.1016/S00796611(02)00061-7, 2002.

Whitney, F. A., Crawford, W. R., and Harrison, P. J.: Physical processes that enhance nutrient transport and primary productivity in the coastal and open ocean of the subarctic NE Pacific, Deep-Sea Res. Pt. II, 52, 681-706, https://doi.org/10.1016/j.dsr2.2004.12.023, 2005.

Wickham, H., François, R., Henry, L., and Müller, K.: dplyr: A Grammar of Data Manipulation, 2019.

Wikner, J. and Andersson, A.: Increased freshwater discharge shifts the trophic balance in the coastal zone of the northern Baltic Sea, Global Change Biol., 18, 2509-2519, https://doi.org/10.1111/j.1365-2486.2012.02718.x, 2012.

Wong, C. S., Yu, Z., Waser, N. A. D., Whitney, F. A., and Johnson, W. K.: Seasonal changes in the distribution of dissolved organic nitrogen in coastal and open-ocean waters in the North East Pacific: sources and sinks, Deep-Sea Res. Pt. II, 49, 5759-5773, https://doi.org/10.1016/S0967-0645(02)00213-8, 2002.

Xenopoulos, M. A., Downing, J. A., Kumar, M. D., Menden-Deuer, S., and Voss, M.: Headwaters to oceans: Ecological and biogeochemical contrasts across the aquatic continuum, Limnol. Oceanogr., 62, 3-14, https://doi.org/10.1002/lno.10721, 2017. 